Gupta, R, Gregg, M and Williams, K

Cooling the UK housing stock post-2050s

Gupta, R, Gregg, M and Williams, K (2015) Cooling the UK housing stock post-2050s. Building Services Engineering Research and Technology, 36 (2). pp. 196-220.

doi: $10.1177 / 0143624414566242$

This version is available: https://radar.brookes.ac.uk/radar/items/8e242fd0-0d30-44a8-a89f-276a46f3c8ea/1/

Available on RADAR: July 2016

Copyright (C) and Moral Rights are retained by the author(s) and/ or other copyright owners. A copy can be downloaded for personal non-commercial research or study, without prior permission or charge. This item cannot be reproduced or quoted extensively from without first obtaining permission in writing from the copyright holder(s). The content must not be changed in any way or sold commercially in any format or medium without the formal permission of the copyright holders.

This document is the post print version of the journal article. Some differences between the published version and this version may remain and you are advised to consult the published version if you wish to cite from it. 
R Gupta PhD MSc BArch,

M Gregg MSc BArch LEED AP, and

K Williams BA DipUD DipUP MSc PhD MRTPI

R Gupta (responsible author)

Low Carbon Building Group, School of Architecture, Oxford Brookes University,

Oxford, Headington Campus, Gipsy Lane, Oxford OX3 OBP

rgupta@brookes.ac.uk

\title{
Cooling the UK housing stock post-2050s
}

\begin{abstract}
This paper investigates the risk of projected post-2050s overheating in existing, retrofitted and new-build dwellings in the UK. As previous research has shown, passive measures may not be sufficient in mitigating overheating risk. Therefore, mechanical cooling technologies that may be deployed to 'adapt' to a warming climate are tested for energy and $\mathrm{CO}_{2}$ implications. For retrofits, heating demand is projected to remain dominant, whereas in post-2016 new-build, greater cooling system efficiency will be important. Thermal mass is shown to reduce future cooling load. The heat recovery element of MVHR may be rendered unnecessary in super-efficient homes. Ceiling fans coupled with natural ventilation may be sufficient in providing thermal comfort in the north of England. Ultimately, not planning for future overheating and cooling systems could create a new performance gap in design, construction and occupant behaviour.
\end{abstract}




\section{Practical application}

Overheating, already experienced in dwellings throughout the UK and projected to increase in occurrence, should be considered in all new design and retrofit.

Dwellings designed to meet thermal comfort performance targets may be at risk of non-compliance as a result of a warming climate. Furthermore, dwellings designed to meet energy performance targets may be at risk of non-compliance as a result of potential need for cooling systems. The findings have implications for policymaking in relation to decarbonisation of the electricity grid, implementation of the Green Deal and upgrading building regulations to future-proof new and existing housing against a warming climate. 


\section{Introduction}

Choices made today in the building sector can have long lasting effects. Whereas in other sectors technological change can take place in 20 years or less, buildings built today can last up to 100 years or beyond. ${ }^{1}$ In the UK over $80 \%$ of existing homes will still be standing in 2050 which emphasises the need for a massive retrofit of existing homes to meet Government $\mathrm{CO}_{2}$ reduction targets ${ }^{2}$. As a result, there is great urgency in reshaping how energy is used and this places significant weight on policy decisions that will impact the way buildings are built or retrofitted throughout the remainder of the decade.

Heating and cooling energy consumption is influenced by the quality of the building envelope, occupant behaviour and the climate ${ }^{1,3}$ Climate change within this century has the potential to make naturally ventilated buildings that have otherwise been at low risk of overheating have thermally unacceptable interior environments. ${ }^{4,5}$ The vast majority of dwellings in the UK are free-running in summer. Though this may suggest the domestic sector in the UK has, for the most part, been sufficiently thermally comfortable throughout the summers, research has shown that this could already be changing, ${ }^{6,7}$ is projected to further change in the future, and will be difficult to passively mitigate beyond the middle of the

century. ${ }^{8,9,10}$ Furthermore, improved standards of airtightness, greater reliance on mechanical ventilation and increased levels of insulation in new-build homes and existing houses driven by National Green Deal' programme and Government's $\mathrm{CO}_{2}$ targets, could aggravate the risk of overheating post-2050s. This explains why building regulations and policy schemes like the Green Deal and Zero Carbon new homes from 2016 will need to integrate probabilistic future climate change analysis in order to future-proof buildings. ${ }^{11}$ 
To further complicate matters, recent research ${ }^{7,8,10}$ has shown that post-2050s, passive measures (thermal mass, night-time ventilation and shading) may not be effective in providing sufficient thermal comfort and that some kind of active cooling systems may be necessary in some locations of the country. Particularly, with further urbanisation and a warmer climate leading to higher urban temperatures and local conditions making natural ventilation less desirable (due to noise, air pollution and security concerns), the move to install domestic air-conditioning would seem obvious and attractive. Heating energy demand is projected to decrease and future cooling demand will increase assuming an uptake of cooling technologies. Collins et al. ${ }^{3}$ demonstrated a projected $26-32 \%$ heating demand reduction by the 2080s. Similar changes have been simulated in Germany, Portugal, Austria ${ }^{12}$ and Slovenia. ${ }^{13}$

These changes will have an impact on the proportion of energy distribution and resultant $\mathrm{CO}_{2}$ emissions since most homes are heated by natural gas. Measures to reduce space heating and water use (or switch from gas to electricity via heat pumps for example) and the expected rise in demand for electrical consumer goods in the future will cause the domestic sector's share of energy use to be increasingly dominated by electricity. ${ }^{3,14}$ The use of gas as a primary domestic fuel source could shift to electricity in the future for two reasons:

1. First, the government focus on heat pumps as a viable heating source through the Renewable Heat Incentive (RHI), the Green Deal and the Affordable Warmth Obligation (funding stream of the Energy Company Obligation for low income and fuel poor) ${ }^{15,16}$ and

2. Second, the potential uptake of air conditioning or heat pumps for future cooling in response to the climatic change projected cooling demand increase in addition to heating demand decrease. , $^{3,8}$ 
Within this context, this paper specifically investigates, through dynamic thermal simulation, the overheating risk posed by a changing climate post-2050s, and the subsequent electricity implications of the potential uptake of cooling technologies in order to 'adapt' typical home types found in the suburban domestic sector. This investigation is performed through case study houses located in three English cities, assuming a responsive uptake of various cooling techniques in the face of climate change and the residual effects of current regulatory measures, such as the Green Deal and the 2016 Zero Carbon new-build target.

\section{Method}

Thermal simulation of future conditions was performed on a number of English suburban house archetypes located in three English cities using Integrated Environmental Solutions Virtual Environment's 'ii (IES VE) ModellT, Apache and VistaPro software. The houses are modelled with current, retrofitted and Zero Carbon new-build characteristics. This section presents the methods used for preparing the investigation and analysing the results.

\subsection{Future weather data for simulation}

Previous research has shown that in some locations in England, homes (depending on a number of different characteristics) are projected to overheat during the 2050s climate period and beyond even after a suite of passive cooling measures are applied. ${ }^{7,8}$ This paper advances the investigation by addressing the concern that passive measures are ineffective in completely mitigating overheating risk. So what will it take to remain thermally comfortable in the climate period following the 2050 s climate period? 
Probabilistic future weather year (FWY) datasets from the UK Climate Projections ${ }^{17}$ (UKCP09) are used to simulate the impact of climatic change. The simulated projections are 2080s climate period (representing potential conditions from 20702099); high emissions scenario (IPCC SRES A1FI), an emissions scenario path roughly being currently followed given the current $\mathrm{CO}_{2}$ emissions and global economic, technical, and social trajectory; ${ }^{18,19}$ and $50-90 \%$ probabilities, allowing the probabilistic range to cover the 'central estimate' $(50 \%)$ to 'very unlikely to be greater than' $(90 \%)$. Design summer year (DSY) files of these projections are used to assess overheating in hot summers but not in extreme or heat wave conditions. The future weather data were attained from the output of the Engineering and Physical Science Research Council (EPSRC)-funded PROMETHEUS project. ${ }^{20}$ FWY files and locations used in the study are listed in table 1.

\section{Table 1}

\subsection{Modelling the domestic archetypes}

Twelve suburban housing archetypes are used for testing (three built-forms over four built-age groups). The built-form archetypes listed in table 2 are the most common housing types in England. ${ }^{21}$ The four built-age groups are pre-1919, 1950s, early-2000s and Zero Carbon Homes (circa-2016).

\section{Table 2}

All homes are modelled and simulated with a south-facing front orientation. That is, the living room (proxy) of each home has primary south facing glazing. South orientation was selected as a beginning default position but it is beyond the scope of the paper to explore all possible orientations. Though the south orientated living 
room has been shown to have moderate overheating relative to other orientations, the living room experiences greater overheating than the bedrooms during respective occupied hours. ${ }^{7}$

\subsection{Baseline construction}

There are three levels of baseline construction (following proportion of English stock): pre-1919 (21\%) solid wall, 1950 s $(20 \%)$ unfilled cavity and early-2000s $(<13 \%)$ filled cavity. ${ }^{21}$ Overheating assessment of baseline construction types include natural ventilation during occupied hours of the summer season. Heating and cooling set-points for the living room are $21^{\circ} \mathrm{C}$ and $23^{\circ} \mathrm{C}$ respectively (midrange domestic recommended operative temperatures ${ }^{22}$ ). Set-points remain the same throughout all simulations (i.e. between the base construction and the Zero Carbon homes) though highly insulated conditions have been shown to provide comfort at lower temperatures due to the radiant heat exchange.$^{23}$ All baseline homes are heated with boilers using natural gas. The boiler efficiency of the pre1919 and 1950 s homes is $70 \%$ and the efficiency for the early-2000s homes is $78 \%$.

Table 3 lists the construction characteristics for each home. Wall and ground floor construction vary with age. Homes pre-2000 are modelled without wall insulation. Alternatively, the pre-1919 and 1950s homes have loft insulation of $100 \mathrm{~mm}$, given that by 2008 roughly $85 \%$ of English homes had $100 \mathrm{~mm}$ or more of loft insulation; ${ }^{24}$ the early-2000s homes have $150 \mathrm{~mm}$ of loft insulation. Furthermore, all homes are modelled with double glazing as by $2008,90 \%$ of households had some level of double glazing ${ }^{24}$ All pre-1919 and 1950s homes are modelled without cylinder or pipework insulation, resulting in higher internal gains. All baseline 
homes have the same internal gains and infiltration rates (1.3 mean dwelling ach).

For axonometrics, plans and room dimensions of the homes see the appendix.

\section{Table 3}

\subsection{Green Deal retrofit}

The Green Deal retrofit is applied to each baseline construction for each archetype and location. Table 4 details the construction changes for the Green Deal retrofitting of the homes. The specific changes are taken from a theoretical Green Deal package outlined in the Department of Energy and Climate Change (DECC) report $^{25}$ on Green Deal implementation planning. Where the homes are solidwalled, internal insulation will be used because it is less expensive than external insulation. ${ }^{25}$ It is presumed that after Green Deal assessment, a majority of homeowners will choose the insulation which will provide the energy savings with the greatest payback benefit due to cost (easier to meet the Golden Ruleiij). In addition, external insulation is expected to face greater opposition when retrofitting older or protected facades. ${ }^{26}$ Cavity wall homes receive both cavity fill insulation and internal insulation to meet the $\mathrm{U}$-value $0.22 \mathrm{~W} / \mathrm{m}^{2} \mathrm{~K}$. This external wall $\mathrm{U}$-value is loosely based on Building Regulations Part L 2013 consultation. ${ }^{27}$ All homes receive a boiler efficiency upgrade of $91 \%$ and water heating system upgrades reduce the internal gains of the homes.

The retrofit changes are intended for space and water heating demand and energy use reduction; however, as the climate changes and overheating becomes a challenge, these measures can be both beneficial and potentially problematic. Insulation, specifically internal insulation, has been shown to increase the risk of overheating (in some cases through the reduction of exposed thermal mass). 
Alternatively, reduction of internal gains from pipework insulation (for example) will help reduce overheating risk and/or future cooling demand. ${ }^{8}$ The Green Deal package does not include passive measures for overheating reduction explored in previous research ${ }^{7,8}$ (e.g. shading). It is not expected that many homeowners will immediately take up shading (for example) as a part of their Green Deal package since without cooling demand, it will not present savings toward the Golden Rule.

\section{Table 4}

\subsection{Zero carbon new-build}

Table 5 lists the construction details for the modelled Zero Carbon ${ }^{\text {iv }}$ homes. For each location there are three built forms (table 2) of Zero Carbon home. The Zero Carbon homes are modelled with decreased air permeability $\left(1 \mathrm{~m}^{3} / \mathrm{h} / \mathrm{m}^{2} @ 50 \mathrm{~Pa}\right)$ and mechanical ventilation with heat recovery (MVHR). MVHR is only used in the heating season; therefore, in the analysis when heating energy and $\mathrm{CO}_{2}$ emissions are calculated the figures include MVHR consumption. The boiler efficiency is $91 \%$.

\section{Table 5}

Though there is awareness of the risk of overheating in new homes ${ }^{28}$ leading to wider application of external shading in the future, shading is not assumed in the current Zero Carbon home model. This is done so that the homes can share this common feature with the other models (in order to reduce variables).

\subsection{Assessing overheating}

$\mathrm{CIBSE}^{29}$ guidance on identifying overheating in conjunction with Integrated Environmental Solution's VistaPro advanced comfort analysis are used to identify 
overheating in all free-running simulations of the homes. The following limitations are present. First, TM52 is designed for non-domestic analysis. Second, though the simulations cover existing, new-build and potentially infirm occupants, Category II, 'normal level of expectation for new buildings and renovations' alone is used to allow for cross-comparison between all variables. Deeper analysis is shown for a select group of houses, specifically looking at criterion 1, where overheating is defined as more than $3 \%$ of total occupied hours exceeding the interior Category II upper threshold.

\section{Overheating in the homes}

Table 6 shows the overheating results (pass or fail) for all homes, locations (except Bristol), and occupancy profiles described in the methodology. When two criteria pass, the home is not 'overheated' (indicated by a box. In most cases $\mathrm{O} 2$ surpasses $\mathrm{O} 1$ in failure for all criteria except criterion 3. Daily weighted exceedance (criterion 2) is generally much higher for $\mathrm{O} 2$ and upper limit temperature (criterion 3 ) is generally the same for both occupant types. Bristol is not shown because every dwelling failed all criteria with the exception of one: $\mathrm{O} 2$ detached Zero Carbon at 50\% probability for criterion 1 . 
Table 6

Figure 1 shows the overheating results for all 01 homes in Stockport according to criterion 1. To illustrate the probabilistic range, the beginning point of each bar in the graph indicates $50 \%$ probability and the end point indicates $90 \%$. Between the three cities, Oxford has the largest probabilistic range of overheating between $50 \%$ and $90 \%$ probabilities and Stockport has the smallest. Only a few homes are able to avoid criterion 1 overheating (Stockport overheats least). The regulatory changes, e.g. Green Deal and Zero Carbon, though not in all cases, can result in homes with less overheating than the control homes. The relatively small reduction in overheating risk is attributable to lower internal gains in the retrofitted homes and in the case of the Zero Carbon homes, a combination of external insulation and higher internal mass appear to be beneficial. The reductions in overheating risk are however not very significant and should be adapted with passive measures. ${ }^{7,8}$

Figure 1 Bristol, Oxford and Stockport overheating. Note: the bars represent the probabilistic range of $50-90 \%$.

Increasing the efficiency of existing constructions will continue to contribute to beneficial reduction of heating demand into the 2080s climate period (figures 2 \& 3). This is also true for the Zero Carbon model, however, analysing the period with the warmest external temperatures outside the summer season, it appears that by the 2080s the cooling season could expand widely in higher efficiency homes. In addition, for Zero Carbon homes there is a risk of overheating outside the summer season (figure 2). 
Figure 2 Bristol temperatures in three variables during the warmest week in 2080s high e. $50 \%$.

The Zero Carbon homes are naturally ventilated in the summer with mechanical ventilation off. However, in the heating season the MVHR is on and in override mode when heating is not necessary. MV without HR is found to beneficially reduce the internal temperature in the heating and shoulder seasons; the internal temperature difference can be $3-4^{\circ} \mathrm{C}$ greater if a sealed home has no MV. As an example, a Zero Carbon home in Bristol during the coldest week in 2080s high emissions $50 \%$ probability had thermally comfortable living room temperatures between $20-23^{\circ} \mathrm{C}$ when the MV operated without HR (figure 3). At the same time if the home was sealed without MV, the living room temperatures were $23-27^{\circ} \mathrm{C}$. This may suggest that climate change will negate the need for MV/MVHR in homes that are able to naturally ventilate in these seasons or at least the heat recovery element of MVHR where secure ventilation is needed.

Figure 3 Bristol temperatures in three variables during the coldest week in 2080s high e. $50 \%$.

The next section will explore cooling options as a route to reducing overheating and the potential energy implications of these systems. Because current $\mathrm{CO}_{2}$ reduction policy is focussed on Green Deal retrofits and Zero Carbon homes, the systems are tested on these homes.

\section{Active cooling}

Four cooling approaches for the future homes using $\mathrm{O} 1$ occupancy are explored in this section. These are fans, heat pumps (with cooling capacity), air-conditioning 
and solar air-conditioning. The cooling methods work to do one or both of the following for the occupants: increase air velocity to affect both convective and evaporative heat losses from the body, and thus influence thermal comfort ${ }^{30}$ and/or physically remove heat from the occupied space.

Assessing the projected future energy use of dwellings using these systems is the ultimate purpose of the investigation. The suitability of particular systems in meeting thermal comfort or determining the ideal future cooling system is not the specific intent. Furthermore, it is beyond the scope of this investigation to estimate system efficiency and results (e.g. extensive samples of performance curves or validation with actual system hourly thermal load data). This would alternatively be recommended for actual case study investigations and not necessarily a broad look at future estimations over a wide range of housing conditions.

The cooling energy use assessment assumes a sealed home for the entire year, i.e., windows are not opened in the simulations. Specifically this scenario results in the greatest potential consumption for each system. Additionally, it can provide a glimpse into the difficult conditions where occupants are restricted from opening windows for comfort due to local noise, pollution or for security purposes. The fan assessment, on the other hand, assumes the same window opening pattern of the free-running homes in the overheating assessment. Though it may seem inconsistent, fan energy is not wasted when windows are open.

\subsection{Fans}

Fans are an inexpensive (in both cost and carbon emissions) tool which can increase the comfort threshold by up to $3^{\circ} \mathrm{K}{ }^{31}$ Fans do not cool the ambient air but can draw in cooler air from outside and/or increase heat loss by increasing the 
efficiency of all normal methods of heat loss, but particularly by evaporation and convection methods. ${ }^{32}$ In addition, ceiling fans at low speeds (below $0.2 \mathrm{~m} / \mathrm{s}$ at head height) have been found to be effective in de-stratification of warm air, reducing heating costs in the heating season. This is particularly more effective in spaces with high ceilings. ${ }^{33}$

The adaptive thermal comfort model suggests that thermal environments slightly warmer than normally preferred can still be acceptable to building occupants, therefore the introduction of airflow with higher velocities (removing sensible and latent heat from the body) can create a more desirable scenario for these occupants. ${ }^{30}$ In one study modelling a fan, Ho et al. ${ }^{34}$ demonstrated that though a ceiling fan distributed the air in the space, mixing in the warmer air from above, slightly increasing the temperature in the space, the chilling effect of the fan increased the sense of thermal comfort in the zone below the fan. There is a limit however; a systematic review ultimately could not support or refute the effectiveness of fan use during heatwaves but suggested that a fan might increase heat loss if the temperature is below $35^{\circ} \mathrm{C}^{32}$

The sufficiency of fans to meet thermal comfort requirements will need to be established before a fan is considered an option against which to compare other energy consumption results. To test the effectiveness of a ceiling fan in an overheated space, the predicted mean vote (PMV) ${ }^{22}$ is used on three sample houses, one from each city. The mid-terrace Zero Carbon homes are selected for assessment due to their relatively higher overheating levels. First, to establish fan air speeds, the air speeds of a domestic ceiling fan and box fan were assessed using an anemometer at approximately $1 \mathrm{~m}$ from the fans (table 7). For the ceiling fan, this distance is based on head height for an individual sitting under the fan. 


\section{Table 7}

Though higher air speeds can be achieved with the use of a box fan pointing directly at the occupant (up to $3-4 \mathrm{~m} / \mathrm{s}$ ), the air speed is restricted at $1.2 \mathrm{~m} / \mathrm{s}$. The reasons for this are:

1. The assessment is done to provide thermal comfort in a relaxed state (ceiling fan above head) as opposed to a heat stressed state (sweating individual standing directly in front of a box fan to cool off).

2. The box fans, with higher speeds, create what is believed to be an unacceptable amount of noise (table 7) considering the typical occupancy activities of a living room, e.g. watching television, having a conversation.

\subsubsection{Thermal comfort and fans}

Figure 4 graphs the internal temperature, mean radiant (M.R.) temperature, relative humidity and the required air speed to reach a PMV of 0 . Static and not graphed are the metabolic rate of 1 and the clothing insulation value of 0.5 . Each graph presents four different days in the 2080s high emissions scenarios for each city. The four days represent in the following order, the day with the:

1. highest internal temperature at $50 \%$ probability

2. second highest internal temperature at $50 \%$ probability

3. highest internal temperature at $90 \%$ probability

4. second highest internal temperature at $90 \%$ probability

Figure 4 Internal thermal comfort conditions using a ceiling fan 
At $50 \%$ probability, thermal comfort in the Oxford and Stockport Zero Carbon midterrace's living rooms appear to be manageable with a ceiling fan. On the hottest day in Oxford the ceiling fan is required at the highest setting for a majority of the evening. In Stockport, a medium or lower setting appears to be sufficient for achieving a PMV of 0 . In Bristol however, on the hottest day, the PMV is 1.5, slightly warm with a $50 \%$ predicted percentage dissatisfied (PPD). At $90 \%$ probability, Oxford changes radically. The hottest day proves to be unacceptable where a majority of the evening is beyond a PMV of 3 (off the graph); a ceiling fan alone would be insufficient for thermal comfort. As the second day shows, thermal comfort is barely manageable and for a majority of the evening $>75 \%$ would be dissatisfied. This is also considered to be insufficient. Stockport, where temperatures remain below $35^{\circ} \mathrm{C}$ for the entire probabilistic range, appears to be manageable with a ceiling fan where at worst, there is $50 \%$ PPD which tapers off quickly on the hottest day at $90 \%$ probability.

To calculate the energy use for a ceiling fan the following assumptions are made:

- The hours for ceiling fan use for each home are simply taken from the number of hours overheated from the preceding overheating analysis; the fan is not used if the temperature is below the Cat. II maximum threshold. In reality, it is recognised that the fan use would not be this rigidly controlled.

- As wattage ratings from fans are given for the highest speed, this wattage will be used as a constant, i.e., lower speed setting, though sufficient for thermal comfort, will not be used to calculate a reduced energy use.

- To best represent the future condition, the wattage rating from the highest efficiency fan available from a manufacturer is used. This is 17.5 Watts for the high speed setting. ${ }^{35}$ 
- Though ceiling fans are considered insufficient to provide thermal comfort above $35^{\circ} \mathrm{C}$, fan energy use is still counted against these hours. The temperature threshold of $35^{\circ} \mathrm{C}$ is shown to determine when the ceiling fan is insufficient in providing thermal comfort.

\subsection{Heat pumps}

Heat pumps are able to heat and cool a home. This makes heat pumps versatile for seasonally distinguishable climates. The basic function of a heat pump is to transfer heat from one body to another. The most common heat pumps in the domestic sector are ground mass to liquid (ground source heat pumps (GSHP)) or air to liquid (air source heat pumps (ASHP)). ${ }^{16}$ Heat pump efficiencies are based on the coefficient of performance (COP) or the ratio of heat energy output to the electrical energy input. The Energy Saving Trust ${ }^{36}$ discovered considerably low actual efficiencies in a field trial of 83 heat pumps throughout the UK (GSHP mean 2.3 and ASHP mean 2.2). According to Gupta and Irving, ${ }^{16}$ a heating COP of greater than 2.6 would be required to justify the carbon intensity of a heat pump as compared to a highly efficient gas fired boiler. According to Lowe,${ }^{14} \mathrm{GSHP}$ technology coupled with plausible developments in electricity supply could result in a fourfold reduction of the carbon intensity as compared with gas boilers. Dwellings with solar photovoltaic panels would help reduce the carbon intensity and justify electrically driven technologies like the heat pump. As an example Zero Carbon homes have the option to use solar PV to meet the second tier, low carbon heat and power technologies, for code compliance.

In the UK, the RHI is a programme similar to the Feed-in Tariff but for heat energy and without the import/export feature. GSHPs and ASHPs (among others) are eligible for the $\mathrm{RHI}$ as long as the COP is greater than $2.9 .{ }^{37}$ Based on this and the 
specifications for an advanced heat pump,$^{38}$ the homes are modelled using an ASHP with a heating COP of 2.97 for $55^{\circ} \mathrm{C}$ water output and an air intake of $7 / 6^{\circ} \mathrm{C}$ (dry/wet). The cooling energy efficiency ratio (EER) is 4.12 for $18^{\circ} \mathrm{C}$ water output and an air intake of $35^{\circ} \mathrm{C}$

\subsection{Standard air conditioning}

The air conditioner (AC), like the heat pump, works to transfer heat from one body to another. Typically ACs work to cool the indoor air by transferring or rejecting heat from a building. Many AC systems also work to regulate the humidity of the indoor air. The heat that is removed from the building, unless used for other purposes is simply rejected to the outside. This aspect is of concern for increasing the heat island effect in urban areas. Alternatively, heat capture such as in an AC with heat recovery for water heating has a twofold energy benefit; heating water and reducing the energy used by the air conditioner for cooling. ${ }^{39}$ Advances such as these are more beneficial than the typical standard AC unit. However, where currently $75 \%$ of mechanical cooling systems are reversible heat, cooling only appliances are expected to disappear from the EU market. ${ }^{40}$ The UK's adoption of EU efficiency standards for heat pumps would suggest that the UK, by the time cooling becomes a necessity, would follow the same trajectory as the EU.

Air conditioning is rated based on its EER. This is the ratio between the output cooling (thermal) power and the input electrical power in cooling mode. The EER is used to define the energy classes for labelling. By 2008, 'Class A' air conditioners held $61 \%$ of the market in Italy and Spain. A 'Class A' EER is 3.2 for systems up to $12 \mathrm{~kW} .{ }^{41}$ For the simulation of standard AC, the Eurovent Class A rating (EER 3.2) is used. For future considerations, this could be a mid-range energy rating by midcentury. 


\subsection{Solar air conditioning}

An advanced version of the air conditioner is the solar-AC or solar absorption chiller. Absorption chillers are currently used primarily in industrial applications but are technologically advancing to be appropriately sized for domestic use and have been tested in domestic applications. Cost is also currently high, but exposure, demand and energy price change could trigger wide marketability in the future. ${ }^{42}$ To cool the house with a domestic scaled absorption chiller, hot water is pumped through an absorption chiller (significantly more efficient than standard ACs). Absorption chilling uses a thermally activated vapour compression cycle, with Lithium Bromide as its absorbent and water as refrigerant. Both substances are environmentally benign. ${ }^{42}$ The absorption cycle is energized by a heat medium (hot water) at $80-85^{\circ} \mathrm{C}$ from a solar thermal energy collector (vacuum tube) or any other available heat source such as industrial waste water or cogeneration system. Storing the hot water allows the system to operate outside of sunshine hours. ${ }^{43}$ Climate change projections $50-90 \%$ probabilities in all locations show an increase in annual and summer mean solar radiation (due to decrease in cloud cover). ${ }^{17}$ Climate change should present greater opportunities for both solar electrical and thermal energy generation

Solar-AC is a highly efficient cooling option (with reported electricity use reductions from $50-70 \%$ ) equivalent to the highest current EER $5.71 .^{41,44,45}$ For the simulation of the future solar-AC, the current, highest EER of 5.71 is used.

\section{Results and discussion}

As is detailed in this section, ceiling fans consume far less energy than the heat pump and AC options. Ceiling fans are an affordable and low energy step-wise solution that can effectively increase the adaptive thermal comfort threshold 
(especially when coupled with other passive solutions). The fan however may not always be sufficient in meeting the thermal comfort needs of the occupant. As is shown in the study the sufficiency of fans to meet thermal comfort needs will depend on the probabilistic intensity of future change.

\subsection{Fan energy use}

Table 8 presents the calculated maximum, mean and minimum energy consumption and occupied hours above $35^{\circ} \mathrm{C}$ considering all Green Deal retrofitted and Zero Carbon homes.

\section{Table 8}

If theoretically we can assume that the ceiling fan has the capacity to create a cooling effect on the occupants at temperatures below $35^{\circ} \mathrm{C}$ where a PPD of $<50 \%$ is attained, this would reset the overheating threshold to $35^{\circ} \mathrm{C}$. In this case, all cities at $50 \%$ probability could attain this equilibrium at low energy cost. Also so could most houses in Stockport at $90 \%$ probability. Houses in Bristol at $90 \%$ probability would have difficulty and houses in Oxford at $90 \%$ probability continue to be severely overheated.

\subsection{Heat pump, $A C$ and solar-AC energy use}

Figure 5 graphs the heat pump energy use for the Green Deal and Zero Carbon houses for the three cities. The following graphs demonstrate annual space heating and cooling only and do not include water heating and unregulated loads.

Figure 5 Heat pump space heating and cooling energy use 
All retrofitted houses demonstrate the same internal gains and occupancy patterns (O1). It appears that from the energy use comparisons, cooling energy use is less affected by the thermal properties of the houses than heating energy requirement (e.g. compare early-2000s with Pre-1919). The Zero Carbon house is significantly different with superlative thermal properties for all elements, greater airtightness levels and MVHR. The Zero Carbon house also has greater internal thermal mass (by a factor of $13 \mathrm{~kJ} /\left(\mathrm{m}^{2} \mathrm{~K}\right)$ ) than the retrofitted homes. An interesting detail is seen in both Bristol and Oxford where the $90 \%$ probability cooling load for the retrofits surpass the Zero Carbon cooling load while at $50 \%$ probability they do not. This can be attributed to the thermal mass properties in the Zero Carbon home, regulating the temperature swings. This feature is notably more beneficial in the $90 \%$ probabilistic projection. The benefit of thermal mass in reducing overheating vulnerability is also demonstrated in Gupta and $\mathrm{Gregg}^{8}$ and Tillson et al. ${ }^{5}$ Figure 6 demonstrates this in the living room temperatures (cooled during occupied hours via heat pump) for two days in Oxford. The temperature swings during the hours that are not cooled are significantly more pronounced in the early-2000s houses at $90 \%$ probability. This state of daily heat 'recovery' requires greater energy use to cool the space.

Figure 6 Temperature swing comparisons for two houses in Oxford at 50 and $90 \%$ probability

Figure 7 graphs the AC energy use for the Green Deal and Zero Carbon houses for the three cities. Space heating is supplied by the high efficiency boiler that is standard for the Green Deal renovated and Zero Carbon houses.

Figure $7 \mathrm{AC}$ and gas boiler energy consumption 
The standard AC cooling energy use follows the same pattern as the heat pump cooling energy use. AC consumption is generally $300-600 \mathrm{kWh}$ higher; this however is simply a factor of the EER of the particular system. In addition, where the heat pump simulation assumes a precise COP, the heating energy use is significantly lower than the boiler which is used alongside the AC in figure 7. As with the heat pump, it appears that the Zero Carbon houses' relative increase in cooling is notably offset by the greater decrease in heating energy. With the $\mathrm{AC} /$ boiler combination, this question should be assessed through $\mathrm{CO}_{2}$ emissions. As an example, table 9 compares the mid-terrace Zero Carbon house with the early-2000s house in Stockport. Given these calculations, higher fabric efficiency is of greater importance when using less efficient equipment for heating; the increased cooling load as a result is of less consequence. This increased electricity demand is potentially further offset by the integration of solar PV on Zero Carbon new-builds as a route to meet full Zero Carbon compliance.

\section{Table 9}

Figure 8 graphs the solar-AC energy use for the Green Deal and Zero Carbon houses in Oxford. As with the standard air conditioning, space heating is supplied by the high efficiency boiler and the consumption is identical. Though only Oxford is shown, Bristol and Stockport consumptions are proportionately similar to those shown in figure 7 , i.e., Bristol at $90 \%$ consumes slightly less than Oxford and is almost identical at $50 \%$. Stockport consumes the least cooling energy.

Figure 8 Oxford solar-AC and gas boiler energy consumption 
Much of the previous analysis remains the same for the application of the solar-AC.

The solar-AC, however, with the greatest EER is the most efficient system for cooling. Though this is true, the heat pump, in complete annual energy use and $\mathrm{CO}_{2}$ emissions is the overall most efficient option for the retrofitted houses. The Zero Carbon houses, because they demand far less heating, perform better with the most efficient cooling option. Table 10 demonstrates this point with two midterrace houses in Stockport.

\section{Table 10}

Table 11 demonstrates through two cases the impact climate change will have on the future $\mathrm{CO}_{2}$ emissions. The future change (comparing standard $\mathrm{AC}$ and heat pump) in carbon emissions is calculated for the Zero Carbon (least heating demand) and pre-1919 (greatest heating demand) versions of a mid-terrace home in Oxford (greatest cooling demand). The calculations demonstrate that, based on current emission factors, the future climate will slightly reduce the carbon emissions of the retrofitted home but will notably increase the $\mathrm{CO}_{2}$ emissions of the Zero Carbon home (discounting a renewable energy source).

\section{Table 11}

This raises a key question: will a Zero Carbon home designed for the current climate remain Zero Carbon? Though there are a number of options for alternatively offsetting $\mathrm{CO}_{2}$ emissions to comply with the proposed Zero Carbon regulation, e.g. solar $\mathrm{PV}$, the Zero Carbon $\mathrm{Hub}^{47}$ proposes that fabric energy efficiency meet a standard (FEES) depending on house typology. For the midterrace home $\left(74 \mathrm{~m}^{2}\right)$ in Oxford, demonstrated in table 11, the maximum energy 
demand for space conditioning (heating and cooling) is $39 \mathrm{kWh} / \mathrm{m}^{2} / \mathrm{yr}$. In the current climate the home is $9 \mathrm{kWh} / \mathrm{m}^{2} / \mathrm{yr}$. Using the most energy intensive adaptation in the study (AC plus boiler) the probabilistic range (50-90\% probability) for the future energy demand is $26-27 \mathrm{kWh} / \mathrm{m}^{2} / \mathrm{yr}$. Therefore, energy demand will rise but the home will remain compliant with FEES in the 2080s at high emissions scenario. Depending on efficiencies of systems and the operational reality (failed commissioning, occupant behaviour, etc.) of the dwelling, there could still be a risk of future non-compliance. Higher EER systems are ideal and in a projected future climate are more important for Zero Carbon homes than higher efficiency heating systems. Alternatively, in thermally less-efficient dwellings, heating system efficiency will remain considerably important.

\subsection{Thermal mass, shading and ventilation}

This paper and other recent work ${ }^{5,7,8,9,10}$ demonstrated that overheating is projected to dramatically impact many built-forms and built-ages throughout England. Overheating is projected to impact a significant portion of house types in the southeast, southwest and north but at $50 \%$ probability some house types in the north, particularly those with high thermal mass and low internal gains may avoid overheating. Though the current study did not focus on a range of previously recommended passive measures, ${ }^{7,8}$ thermal mass should be assessed for its benefit in reducing overheating and subsequent cooling load and extreme temperature swings. Because thermal mass can be present in existing housing, external (as opposed to internal) insulation is recommended where applicable.

Though not tested in the current study, external shading, which had the greatest impact in reducing overheating hours, ${ }^{7,8}$ is highly recommended for both Green Deal retrofitted dwellings and Zero Carbon Homes in order to reduce cooling 
demand. Currently, however, a barrier to external shading exists where for example; a policy like the Green Deal depends on current fuel bill reduction to justify measures. Without assessment of probabilistic future change, the benefit of shading cannot be realised with the exception of a small number of cases. Ideally, passive measures like external shading will precede exploration of active cooling in the domestic sector.

In some projections, the MVHR energy use outweighs the heating energy demand in the Zero Carbon home. As Sassi ${ }^{23}$ demonstrated through post-occupancy evaluation of a Passivhaus flat in Cardiff, an occupant lived comfortably not knowing how to turn on the MVHR, ventilating as per need and using only $40 \%$ of the predicted primary energy use. As the climate in the UK warms and highly insulated homes show almost no need for heating, MVHR or specifically the heat recovery element of MV may be rendered unnecessary. Ventilation, however, is always essential.

Future investigations could evaluate the detailed impact of a number of passive measures on the reduction of cooling demand, a wide range of COPs and EERs for systems, different occupancy patterns, dwellings ages, location and orientations. In addition, future work should evaluate the implications of a widespread uptake of active cooling on the National Grid. In the EU, the fast uptake and extensive summer use of small residential air conditioners in Italy, Spain, Greece and southern France are among the main drivers for increases in electricity consumption and power peak $;^{41}$ clearly the electrical power structure will need to adapt to accommodate a likewise reaction in the UK. The National $\mathrm{Grid}^{48}$ is currently balancing the uptake of heat pumps, modelling a ten-fold increase in electricity demand contribution to domestic heat by 2050 and the regulatory 
requirements for carbon emissions reductions. Decarbonising the electricity grid ahead of these potential changes is essential. As a result, grid projections include almost completely phasing out coal by 2025, phasing out gas by 2050 and increasing wind generation by roughly $130 \%$. ${ }^{48}$

\section{Conclusion}

The future climate is projected to change the thermal comfort conditions in England. There is much potential to adapt to this feasibly and effectively by exhausting passive measures first, and then seeking the most efficient active systems possible when absolutely necessary. This may indicate a shift from gas to electricity but with a projected future solar radiation increase and scaling-up of home or community-level electricity generation (solar PV, solar farms, wind turbines, CHP) the UK could be on a path to create a culture and economy of decentralised energy supply and management whilst gradually shifting the grid from one fuel to the next.

As the climate warms in the future, UK dwellings may be required to accommodate unfamiliar technologies (such as mechanical cooling) to meet thermal comfort needs. These changes will likely impact design and require commissioning, maintenance and further occupant training and education. If adequate foresight is not put into planning for these systems, there is a risk that a new performance gap would be created in design, construction and occupant behaviour, leading in increase in energy use and associated $\mathrm{CO}_{2}$ emissions. 


\section{Appendix}

The modelled house forms are shown below in figures A.1 - A.3. The dimensions and forms of all homes are adapted from Allen and Pinney ${ }^{49}$

Figure A.1 Perspective image, site plan and floor plans of the detached home

Figure A.2 Perspective image, site plan and floor plans of the semi-detached home

Figure A.3 Perspective image, site plan and floor plans of the mid-terrace home 


\section{References}

1. Butera F. Climatic change and the built environment. Advances in Building Energy Research 2010; 4: 45-75.

2. University of Oxford. Home truths: A low-carbon strategy to reduce UK housing emissions $80 \%$ by 2050. Oxford: University of Oxford, 2007

3. Collins L, Natarajan S, Levermore G. Climate change and future energy consumption in UK housing stock. Building Services Engineering Research \& Technology 2010; 31(1): 75-90.

4. Lomas K, Ji Y. Resilience of naturally ventilated buildings to climate change: Advanced natural ventilation and hospital wards. Energy and Buildings 2009; 41: 629-653.

5. Tillson A, Oreszczyn T, Palmer J. Assessing impacts of summertime overheating: some adaptation strategies. Building Research and Information 2013; 41(6): 652-661.

6. Lomas K, Kane T. Summertime temperatures and thermal comfort in UK homes. Building Research and Information, 2013; 41(3): 259-280.

7. Gupta R, Gregg M. Preventing the overheating of English suburban homes in a warming climate. Building Research and Information 2013; 41(3): 281300.

8. Gupta R, Gregg M. Using UK climate change projections to adapt existing English homes for a warming climate. Building and Environment 2012; 55: $20-42$

9. Mavrogianni A, Wilkinson P, Davies M, Biddulph P, Oikonomou E. Building characteristics as determinants of propensity to high indoor summer temperatures in London dwellings. Building and Environment 2012; 55: $117-130$. 
10. Porritt S, Cropper P, Shao L, Goodier C. Ranking of interventions to reduce dwelling overheating during heat waves. Energy and Buildings 2012; 55: 16-27.

11. Georgiadou MC, Hacking T, Guthrie P. Future-proofed energy design for dwellings: Case studies from England and application to the Code for Sustainable Homes. Building Services Engineering Research \& Technology 2012; 34(1): 9-22.

12. Olonscheck M, Holsten A, Kropp JP. Heating and cooling energy demand and related emissions of the German residential building stock under climate change. Energy Policy. 2011; 39(9): 4795-4806.

13. Dolinar M, Vidrih B, Kajfez-Bogataj L, Medved S. Predicted changes in energy demands for heating and cooling due to climate change. Physics and Chemistry of the Earth 2010; 35: 100-106.

14. Lowe R. Technical options and strategies for decarbonizing UK housing. Building Research \& Information 2007; 35(4): 412-425.

15. Department of Energy and Climate Change. Which energy efficiency improvements qualify for Green Deal Finance?; 2011.

https://www.gov.uk/government/uploads/system/uploads/attachment data/f ile/48406/5504-which-energy-efficiency-improvements-qualify-for-g.pdf (accessed 20 April 2013).

16. Gupta R, Irving R. Development and application of a domestic heat pump model for estimating $\mathrm{CO} 2$ emissions reductions from domestic space heating, hot water and potential cooling demand in the future. Energy and Buildings 2013; 60: 60-74.

17. Department for Environment, Food and Rural Affairs. UK climate projections user interface http://ukclimateprojectionsui.defra.gov.uk/ui/admin/login.php (accessed 29 April 2013). 
18. European Environment Agency. Observed global fossil fuel $\mathrm{CO} 2$ emissions compared with six scenarios from the IPCC; 2011.

http://www.eea.europa.eu/data-and-maps/figures/observed-global-fossilfuel-co2 (accessed 26 April 2013).

19. International Energy Agency. Global carbon-dioxide emissions increase by $1.0 \mathrm{Gt}$ in 2011 to record high.

http://www.iea.org/newsroomandevents/news/2012/may/name,27216,en.ht ml (accessed 29 April 2013).

20. Eames M, Kershaw T, Coley D. On the creation of future probabilistic design weather years from UKCP09. Building Services Engineering Research and Technology 2011; 32(2): 127-142.

21. Department for Communities and Local Goverment. English housing survey: Headline report 2011-12; 2013.

https://www.gov.uk/government/uploads/system/uploads/attachment data/f ile/88370/EHS Headline Report 2011-2012.pdf (accessed 20 April 2013).

22. Chartered Institution of Building Services Engineers. CIBSE Guide A. Environmental Design. London: The Chartered Institution of Building Services Engineers; 2007.

23. Sassi P. A natural ventilation alternative to the Passivhaus Standard for a mild maritime climate. Buildings. 2012; 3: 61-78.

24. Palmer J, Cooper I. United Kingdom housing energy fact file; 2013. https://www.gov.uk/government/uploads/system/uploads/attachment_data/f ile/274766/uk_housing_fact_file_2013.pdf (accessed 24 July 2014).

25. Department of Energy and Climate Change. Research report: How to explain the Green Deal; 2012.

https://www.gov.uk/government/uploads/system/uploads/attachment data/f ile/42993/5512-research-report-how-to-explain-the-green-deal.pdf \& 
Appendix 1: Policy questions; 2012.

https://www.gov.uk/government/uploads/system/uploads/attachment data/f $\underline{\text { ile/42996/5515-green-deal--research-on-how-to-explain-the-green-.pdf }}$ (accessed 17 April 2013).

26. Lonsdale S. Getting lost in a maze of Green Deal red tape. The Telegraph. November 62012.

http://www.telegraph.co.uk/property/greenproperty/9658567/Getting-lost-ina-maze-of-Green-Deal-red-tape.html (accessed 29 April 2013).

27. Zero Carbon Hub. Fabric energy efficiency for Part L 2013: Worked examples and fabric specifications, 2012. http://www.zerocarbonhub.org/resourcefiles/fabric standards for 2013 w orked examples.pdf (accessed 29 April 2013).

28. Zero Carbon Hub. Overheating in homes: An introduction for planners, designers and property owners, 2013. http://www.zerocarbonhub.org/resourcefiles/OverheatingInHomes8pp 201 3 8March.pdf (accessed 29 April 2013).

29. Chartered Institution of Building Services Engineers. CIBSE TM52. The limits of thermal comfort: avoiding overheating in European Buildings. London: The Chartered Institution of Building Services Engineers; 2013.

30. Cândido C, Lamberts R, de Dear R, Bittencourt L, de Vecchi R. Towards a Brazilian standard for naturally ventilated buildings: guidelines for thermal and air movement acceptability. Building Research and Information 2011; 3: $145-153$.

31. Rijal H, Tuohy P, Humphreys M, Nicol J, Samuel A. Considering the impact of situation-specific motivations and constraints in the design of naturally ventilated and hybrid buildings. Architectural Science Review 2013; 55(1): 35-48. 
32. Gupta S, Carmichael C, Simpson C, Clarke M, Allen C, Gao Y, Chan E, Murray V. Electric fans for reducing adverse health impacts in heatwaves. Cochrane Database of Systematic Reviews 2012; 7.

33. Aynsley R. How much do you need to know to effectively utilize large ceiling fans? Architectural Science review 2012; 55(1): 15-25.

34. Ho S, Rosario L, Rahman M. Thermal comfort enhancement by using a ceiling fan. Applied Thermal Engineering 2009; 29: 1648-1656.

35. Emerson Climate Technologies. Midway Eco. http://www.emersonfans.com/Pages/Fan.aspx?Fan=Midway+Eco\&ltem=C F955WW (accessed 7 May 2013).

36. Energy Saving Trust. Getting warmer: a field trial of heat pumps; 2010. http://www.heatpumps.org.uk/PdfFiles/TheEnergySavingTrustGettingWarmerAFieldTrialOfHeatPumps.pdf (accessed 26 April 2013).

37. Department of Energy and Climate Change. Renewable Heat Incentive: Air to Water Heat Pumps \& Energy from Waste; 2012 https://www.gov.uk/government/uploads/system/uploads/attachment data/f $\underline{\text { ile/66605/6452-renewable-heat-incentive-air-to-water-heat-pumps-.pdf }}$ (accessed 10 September 2014).

38. Evinox. COP 5 - Most Efficient Air Source Heat Pump in the UK. http://www.evinox.co.uk/Sites/Evinox/library/files/PHRIE\%20ASHP\%20Dat a\%20Sheet.pdf (accessed 26 April 2013).

39. HotSpot Energy This 1.5 ton air conditioner saves electricity and makes 100 gallons of free hot water per day; 2010.

http://www.hotspotenergy.com/air-conditioner-water-heaters/ (accessed 29 April 2013).

40. Michel A, Bush E, Nipkow J, Brunner CU, Bo H. Energy efficient room air conditioners - best available technology. Topten International Services, no 
date http://www.topten.ch/uploads/File/023 Anette Michel final paper.pdf (accessed 10 September 2014).

41. Bertoldi P, Atanasiu B. Electricity Consumption and Efficiency Trends in European Union - Status Report 2009, 2009 http://re.jrc.ec.europa.eu/energyefficiency/pdf/EnEff Report 2009.pdf (accessed 26 April 2013).University of Cincinnati. [re]form house: technology. http://solar.uc.edu/solar2007/technology (accessed 29 April 2013).

42. Sakura. Sakura Developed Mini Solar Absorption Chiller. http://www.sakuraaircon.com/News/Sakura Developed Mini Solar Absorption Chiller.html (accessed 29 April 2013).

43. Atlantis Solar. Solar Air Conditioner Details. http://www.atlantissolar.com/ac details.html (accessed 26 April 2013).

44. Sunflower Solar. Frequently question of Solar Air Conditioner; 2013. http://www.sunflowersolar.com/index es.php?act=content\&scheduler id=424 (accessed 29 April 2013).

45. Carbon Trust. Conversion factors, 2013. http://www.carbontrust.com/media/18223/ctl153 conversion factors.pdf (accessed 10 September 2014).

46. Zero Carbon Hub. Zero carbon strategies for tomorrow's new homes, 2013.

http://www.zerocarbonhub.org/resourcefiles/ZeroCarbonStrategies web.pd f (accessed 29 April 2013).

47. National Grid. UK future energy scenarios; 2011 http://www.nationalgrid.com/NR/rdonlyres/86C815F5-0EAD-46B5-A580- 
$\underline{\text { A0A516562B3E/50819/10312 } 1 \text { NG Futureenergyscenarios WEB1.pdf }}$ (accessed 29 April 2013).

48. Allen EA, Pinney AA. Standard dwellings for modelling: details of dimensions, construction and occupancy schedules. Technical note 90/2. Watford: Building Environmental Performance Analysis Club; 1990.

49. Gough M, Rees C. Tests performed on ApacheSim in accordance with ANSI/ASHRAE Standard 140-2001. Glasgow: IES Ltd.; 2004.

50. IES VE. Space-heating equipment performance tests performed on ApacheSim in accordance with ANSI/ASHRAE Standard 140-2007; 2010. http://www.iesve.com (accessed 7 July 2012).

51. IES VE. Space-cooling equipment performance tests performed on ApacheSim in accordance with ANSI/ASHRAE Standard 140-2007; 2011. http://www.iesve.com (accessed 7 July 2012). 


\section{Acknowledgements}

The authors gratefully acknowledge the PROMETHEUS team at the University of

Exeter for their work in creating the future weather files which were used in this research. 


\section{Tables}

Table 1 Location and FWY information (external conditions)

\begin{tabular}{|l|l|r|r|}
\hline $\begin{array}{l}\text { City (UKCP09 5km } \\
\text { grid sq.) }\end{array}$ & FWY & $\begin{array}{l}\text { Summer mean } \\
{\left[{ }^{\circ} \mathbf{C}\right]}\end{array}$ & $\begin{array}{l}\text { Summer hrs. } \mathbf{3} 0^{\circ} \mathbf{C} \\
{[\%]}\end{array}$ \\
\hline \multirow{3}{*}{ Bristol (3600175) } & $\begin{array}{l}2080 \text { high emissions } \\
50 \%\end{array}$ & 20.39 & 3.6 \\
\cline { 2 - 4 } & $\begin{array}{l}2080 \text { high emissions } \\
90 \%\end{array}$ & 23.52 & 14.4 \\
\hline \multirow{3}{*}{ Oxford (4550210) } & $\begin{array}{l}2080 \text { high emissions } \\
50 \%\end{array}$ & 20.20 & 2.7 \\
\cline { 2 - 5 } & $\begin{array}{l}2080 \text { high emissions } \\
90 \%\end{array}$ & 23.82 & 18.9 \\
\hline \multirow{3}{*}{ Stockport (3900390) } & $\begin{array}{l}2080 \text { high emissions } \\
50 \%\end{array}$ & 19.33 & 0.7 \\
\cline { 2 - 5 } & $\begin{array}{l}2080 \text { high emissions } \\
90 \%\end{array}$ & 22.30 & 8.0 \\
\hline
\end{tabular}


Table 2 House archetype details and characteristics

\begin{tabular}{|c|c|c|c|}
\hline \multirow{2}{*}{ Type } & \multirow{2}{*}{$\begin{array}{l}\text { \% of type } \\
\text { in England }\end{array}$} & \multirow{2}{*}{ Area } & \multirow{3}{*}{$\begin{array}{l}\text { Occupant details } \\
\text { O1: Two working adults without dependants: } \\
\text { living room occupancy: 17:30-22:30, } \\
\text { heating/cooling pattern: 7:00-9:00 \& 16:00-23:00, } \\
\text { heating: } 1 \text { Oct - } 30 \text { April / cooling: } 1 \text { May - } 30 \text { Sept }^{\text {b }}\end{array}$} \\
\hline & & & \\
\hline Detached & $17 \%$ & $\begin{array}{l}98 \\
m^{2}\end{array}$ & \\
\hline $\begin{array}{l}\text { Semi- } \\
\text { detached }\end{array}$ & $\begin{array}{l}26 \% \\
(36 \%)^{a}\end{array}$ & $\begin{array}{l}84 \\
m^{2}\end{array}$ & $\begin{array}{l}\text { heating: } 1 \text { Oct - } 30 \text { April / cooling: } 1 \text { May - } 30 \text { Sept }^{\circ} \\
\text { O2: Two non-working adults without dependants: }\end{array}$ \\
\hline $\begin{array}{l}\text { Mid- } \\
\text { terrace }\end{array}$ & $19 \%$ & $\begin{array}{l}74 \\
m^{2}\end{array}$ & $\begin{array}{l}\text { living room occupancy: 9:00-22:30 ( } 30 \% \text { intensity } \\
\text { from 14:00-17:00), } \\
\text { heating/cooling pattern: 7:00-23:00, } \\
\text { heating: } 1 \text { Oct - } 30 \text { April / cooling: } 1 \text { May - } 30 \text { Sept }^{b}\end{array}$ \\
\hline
\end{tabular}

a $36 \%$ includes the end-terrace type

${ }^{b}$ The heating season and cooling seasons were kept constant through the projections. This is justified by the responsiveness of the system to a set-point as opposed to continuous heating or cooling on at all times. In all scenarios without mechanical cooling, windows are open during occupancy hours when temperatures are above $22^{\circ} \mathrm{C}$ in the cooling season. 
Table 3 Construction details for the baseline homes

\begin{tabular}{|c|c|c|c|c|c|}
\hline Construction & Materials & $\begin{array}{l}\text { U-value } \\
{\left[\mathrm{W} / \mathrm{m}^{2} \mathrm{~K}\right]}\end{array}$ & $\begin{array}{l}\text { Pre- } \\
1919\end{array}$ & 1950s & 2000s \\
\hline Glazing & uPVC double glazing & 2.0 & $\checkmark$ & $\checkmark$ & $\sqrt{ }$ \\
\hline $\begin{array}{l}\text { Internal and } \\
\text { party walls }\end{array}$ & $16 \mathrm{~mm}$ plaster $-105 \mathrm{~mm}$ brick $-16 \mathrm{~mm}$ plaster & N/A & $\sqrt{ }$ & $\sqrt{ }$ & $\sqrt{ }$ \\
\hline Internal floors & $\begin{array}{l}10 \mathrm{~mm} \text { plasterboard }-200 \mathrm{~mm} \text { cavity (floor joists) }- \\
20 \mathrm{~mm} \text { timber flooring }-10 \mathrm{~mm} \text { carpet }\end{array}$ & N/A & $\checkmark$ & $\checkmark$ & $\sqrt{ }$ \\
\hline Roof & $\begin{array}{l}\text { 16mm plasterboard }-100 \mathrm{~mm} \text { glass fibre quilt }- \\
\text { loft space }-7 \mathrm{~mm} \text { tiling board }-10 \mathrm{~mm} \text { roofing tiles }\end{array}$ & 0.35 & $\checkmark$ & $\sqrt{ }$ & \\
\hline $\begin{array}{l}\text { Roof } \\
(2002-2006)\end{array}$ & $\begin{array}{l}16 \mathrm{~mm} \text { plasterboard }-150 \mathrm{~mm} \text { glass fibre quilt }- \\
\text { loft space }-7 \mathrm{~mm} \text { tiling board }-10 \mathrm{~mm} \text { roofing tiles }\end{array}$ & 0.2 & & & $\sqrt{ }$ \\
\hline $\begin{array}{l}\text { Ground floor } \\
(1900-1944)\end{array}$ & $\begin{array}{l}\text { Clay soil }-150 \mathrm{~mm} \text { cavity }-100 \mathrm{~mm} \text { cavity (floor } \\
\text { joists) }-20 \mathrm{~mm} \text { timber flooring }-10 \mathrm{~mm} \text { carpet }\end{array}$ & 1.5 & $\sqrt{ }$ & & \\
\hline $\begin{array}{l}\text { Ground floor } \\
(1950-1976)\end{array}$ & $\begin{array}{l}\text { Clay soil }-100 \mathrm{~mm} \text { concrete slab }-38 \mathrm{~mm} \text { floor } \\
\text { screed }-10 \mathrm{~mm} \text { carpet }\end{array}$ & 1.5 & & $\sqrt{ }$ & \\
\hline $\begin{array}{l}\text { Ground floor } \\
(2002-2006)\end{array}$ & $\begin{array}{l}\text { Clay soil }-120 \mathrm{~mm} \text { insulation }-100 \mathrm{~mm} \text { concrete } \\
\text { slab }-38 \mathrm{~mm} \text { floor screed }-10 \mathrm{~mm} \text { carpet }\end{array}$ & 0.25 & & & $\sqrt{ }$ \\
\hline $\begin{array}{l}\text { External walls } \\
(1900-1919)\end{array}$ & 105mm brick -105mm brick - 16mm plaster & 2.0 & $\sqrt{ }$ & & \\
\hline $\begin{array}{l}\text { External walls } \\
(1930-1976)\end{array}$ & $\begin{array}{l}105 \mathrm{~mm} \text { brick }-50 \mathrm{~mm} \text { cavity }-100 \mathrm{~mm} \text { concrete } \\
\text { block }-16 \mathrm{~mm} \text { plaster }\end{array}$ & 1.4 & & $\sqrt{ }$ & \\
\hline $\begin{array}{l}\text { External walls } \\
(2002-2006)\end{array}$ & $\begin{array}{l}105 \mathrm{~mm} \text { brick }-70 \mathrm{~mm} \text { insulation }-100 \mathrm{~mm} \\
\text { concrete block }-16 \mathrm{~mm} \text { plaster }\end{array}$ & 0.35 & & & $\checkmark$ \\
\hline
\end{tabular}


Table 4 Construction details for the Green Deal retrofitted homes (bold text indicates change)

\begin{tabular}{|c|c|c|c|c|c|}
\hline Construction & Materials/ Details & $\begin{array}{l}\text { U-value } \\
{\left[\mathrm{W} / \mathrm{m}^{2} \mathrm{~K}\right]}\end{array}$ & $\begin{array}{l}\text { Pre- } \\
1919\end{array}$ & 1950s & $2000 s$ \\
\hline Glazing & No change & 2.0 & $\checkmark$ & $\checkmark$ & $\sqrt{ }$ \\
\hline $\begin{array}{l}\text { Internal and } \\
\text { party walls }\end{array}$ & No change & $\mathrm{N} / \mathrm{A}$ & $\sqrt{ }$ & $\sqrt{ }$ & $\sqrt{ }$ \\
\hline Internal floors & No change & $\mathrm{N} / \mathrm{A}$ & $\sqrt{ }$ & $\sqrt{ }$ & $\sqrt{ }$ \\
\hline Roof & $\begin{array}{l}\text { 16mm plasterboard }-\mathbf{2 7 0} \mathbf{m m} \text { glass fibre quilt }- \\
\text { loft space }-7 \mathrm{~mm} \text { tiling board }-10 \mathrm{~mm} \text { roofing tiles }\end{array}$ & 0.14 & $\checkmark$ & $\sqrt{ }$ & $\sqrt{ }$ \\
\hline Ground floor & No change & 1.4 & $\sqrt{ }$ & $\sqrt{ }$ & $\sqrt{ }$ \\
\hline $\begin{array}{l}\text { External walls } \\
(1900-1919)\end{array}$ & $\begin{array}{l}105 \mathrm{~mm} \text { brick }-105 \mathrm{~mm} \text { brick }-100 \mathrm{~mm} \text { internal } \\
\text { insulation }-16 \mathrm{~mm} \text { plaster }\end{array}$ & 0.22 & $\sqrt{ }$ & & \\
\hline $\begin{array}{l}\text { External walls } \\
(1930-1976)\end{array}$ & $\begin{array}{l}105 \mathrm{~mm} \text { brick }-\mathbf{5 0 m m} \text { cavity fill insulation }- \\
100 \mathrm{~mm} \text { concrete block }-60 \mathrm{~mm} \text { internal } \\
\text { insulation }-16 \mathrm{~mm} \text { plaster }\end{array}$ & 0.22 & & $\checkmark$ & \\
\hline $\begin{array}{l}\text { External walls } \\
(2002-2006)\end{array}$ & $\begin{array}{l}105 \mathrm{~mm} \text { brick }-70 \mathrm{~mm} \text { insulation }-100 \mathrm{~mm} \\
\text { concrete block }-40 \mathrm{~mm} \text { internal insulation }- \\
16 \mathrm{~mm} \text { plaster }\end{array}$ & 0.22 & & & $\sqrt{ }$ \\
\hline
\end{tabular}


Table 5 Construction details for the Zero Carbon home

\begin{tabular}{|l|l|r|}
\hline Construction & Materials & U-value [W/m $\left.{ }^{2} \mathbf{K}\right]$ \\
\hline Glazing & Timber frame triple glazing & 0.7 \\
\hline $\begin{array}{l}\text { Internal and } \\
\text { party walls }\end{array}$ & $16 \mathrm{~mm}$ plaster - 105mm brick - 16mm plaster & N/A \\
\hline Internal floors & $\begin{array}{l}10 \mathrm{~mm} \text { plasterboard - 200mm cavity (floor joists) - 20mm timber flooring } \\
-10 \mathrm{~mm} \text { carpet }\end{array}$ & N/A \\
\hline Roof & $\begin{array}{l}16 \mathrm{~mm} \text { plasterboard - 350mm glass fibre quilt - loft space }-7 \mathrm{~mm} \text { tiling } \\
\text { board - 10mm roofing tiles }\end{array}$ & 0.11 \\
\hline Ground floor & $\begin{array}{l}\text { Clay soil - gravel - 200mm under slab insulation - 100mm concrete } \\
\text { slab - 38mm floor screed }\end{array}$ & 0.11 \\
\hline External walls & $\begin{array}{l}100 \mathrm{~mm} \text { external insulation - 105mm block - 100mm insulation - } \\
100 \mathrm{~mm} \text { block - 16mm plaster }\end{array}$ & 0.11 \\
\hline
\end{tabular}


Table 6 Overheating results for all homes in Oxford and Stockport (pass or fail)

\begin{tabular}{|c|c|c|c|c|c|c|c|c|c|c|c|c|c|c|}
\hline \multirow{3}{*}{\multicolumn{3}{|c|}{ Criterion: }} & \multicolumn{6}{|c|}{ Occupant type 1 (01) } & \multicolumn{6}{|c|}{ Occupant type 1 (02) } \\
\hline & & & \multicolumn{3}{|c|}{ 2080s H 50\% } & \multicolumn{3}{|c|}{ 2080s H $90 \%$} & \multicolumn{3}{|c|}{ 2080s H 50\% } & \multicolumn{3}{|c|}{ 2080s H $90 \%$} \\
\hline & & & 1 & 2 & 3 & 1 & 2 & 3 & 1 & 2 & 3 & 1 & 2 & 3 \\
\hline \multirow{21}{*}{$\begin{array}{l}\frac{0}{0} \\
\frac{0}{x} \\
\text { ô }\end{array}$} & \multirow{3}{*}{$\begin{array}{l}\text { Pre-1919 } \\
\text { baseline }\end{array}$} & D & $\mathrm{F}$ & $\mathrm{F}$ & $\mathrm{P}$ & $\mathrm{F}$ & $\mathrm{F}$ & $\mathrm{F}$ & $\mathrm{F}$ & $\mathrm{F}$ & $P$ & $\mathrm{~F}$ & $\mathrm{~F}$ & $\mathrm{~F}$ \\
\hline & & SD & $\mathrm{F}$ & $\mathrm{F}$ & $\mathrm{P}$ & $\mathrm{F}$ & $\mathrm{F}$ & $\mathrm{F}$ & $\mathrm{F}$ & $\mathrm{F}$ & $P$ & $\mathrm{~F}$ & $\mathrm{~F}$ & $\mathrm{~F}$ \\
\hline & & MT & $\mathrm{F}$ & $\mathrm{F}$ & $\mathrm{P}$ & $\mathrm{F}$ & $\mathrm{F}$ & $\mathrm{F}$ & $\mathrm{F}$ & $\mathrm{F}$ & $P$ & $\mathrm{~F}$ & $\mathrm{~F}$ & $\mathrm{~F}$ \\
\hline & \multirow{3}{*}{$\begin{array}{c}1950 \mathrm{~s} \\
\text { baseline }\end{array}$} & D & $F$ & $\mathrm{~F}$ & $P$ & $\mathrm{~F}$ & $\mathrm{~F}$ & $\mathrm{~F}$ & $\mathrm{~F}$ & $\mathrm{~F}$ & $P$ & $\mathrm{~F}$ & $\mathrm{~F}$ & $\mathrm{~F}$ \\
\hline & & SD & $\mathrm{F}$ & $\mathrm{F}$ & $P$ & $\mathrm{~F}$ & $\mathrm{~F}$ & $\mathrm{~F}$ & $\mathrm{~F}$ & $\mathrm{~F}$ & $\mathrm{P}$ & $\mathrm{F}$ & $\mathrm{F}$ & $\mathrm{F}$ \\
\hline & & MT & $\mathrm{F}$ & $\mathrm{F}$ & $P$ & $\mathrm{~F}$ & $\mathrm{~F}$ & $\mathrm{~F}$ & $\mathrm{~F}$ & $\mathrm{~F}$ & $P$ & $\mathrm{~F}$ & $\mathrm{~F}$ & $\mathrm{~F}$ \\
\hline & \multirow{3}{*}{$\begin{array}{c}2000 \text { s } \\
\text { baseline }\end{array}$} & D & $\mathrm{F}$ & $\mathrm{F}$ & $\mathrm{P}$ & $\mathrm{F}$ & $\mathrm{F}$ & $\mathrm{F}$ & $\mathrm{F}$ & $\mathrm{F}$ & $P$ & $\mathrm{~F}$ & $\mathrm{~F}$ & $\mathrm{~F}$ \\
\hline & & SD & $\mathrm{F}$ & $\mathrm{F}$ & $\mathrm{P}$ & $\mathrm{F}$ & $\mathrm{F}$ & $\mathrm{F}$ & $\mathrm{F}$ & $\mathrm{F}$ & $P$ & $\mathrm{~F}$ & $\mathrm{~F}$ & $\mathrm{~F}$ \\
\hline & & MT & $\mathrm{F}$ & $\mathrm{F}$ & $\mathrm{F}$ & $\mathrm{F}$ & $\mathrm{F}$ & $\mathrm{F}$ & $\mathrm{F}$ & $\mathrm{F}$ & $\mathrm{F}$ & $\mathrm{F}$ & $\mathrm{F}$ & $\mathrm{F}$ \\
\hline & \multirow{3}{*}{$\begin{array}{c}\text { Pre-1919 } \\
\text { green deal }\end{array}$} & D & $F$ & $F$ & $P$ & $F$ & $F$ & $\mathrm{~F}$ & $F$ & $F$ & $\mathrm{~F}$ & $F$ & $F$ & $F$ \\
\hline & & SD & $\mathrm{F}$ & $F$ & $P$ & $F$ & $F$ & $\mathrm{~F}$ & $F$ & $F$ & $P$ & $F$ & $F$ & $F$ \\
\hline & & MT & $F$ & $F$ & $P$ & $F$ & $F$ & $\mathrm{~F}$ & $F$ & $F$ & $P$ & $F$ & $\mathrm{~F}$ & $\mathrm{~F}$ \\
\hline & \multirow{3}{*}{$\begin{array}{c}1950 \mathrm{~s} \\
\text { green deal }\end{array}$} & D & $F$ & $F$ & $P$ & $F$ & $F$ & $\mathrm{~F}$ & $F$ & $F$ & $\mathrm{~F}$ & $F$ & $F$ & $F$ \\
\hline & & SD & $F$ & $F$ & $P$ & $F$ & $F$ & $\mathrm{~F}$ & $F$ & $F$ & $P$ & $F$ & $F$ & $F$ \\
\hline & & MT & $F$ & $F$ & $P$ & $F$ & $F$ & $\mathrm{~F}$ & $F$ & $F$ & $P$ & $F$ & $F$ & $F$ \\
\hline & \multirow{3}{*}{$\begin{array}{l}2000 \mathrm{~s} \\
\text { green deal }\end{array}$} & D & $F$ & $F$ & $P$ & $F$ & $F$ & $\mathrm{~F}$ & $F$ & $F$ & $P$ & $F$ & $F$ & $F$ \\
\hline & & SD & $\mathrm{F}$ & $F$ & $P$ & $F$ & $F$ & $\mathrm{~F}$ & $\mathrm{~F}$ & $F$ & $\mathrm{P}$ & $F$ & $\mathrm{~F}$ & $F$ \\
\hline & & MT & $\mathrm{F}$ & $\mathrm{F}$ & $P$ & $F$ & $F$ & $\mathrm{~F}$ & $F$ & $F$ & $\mathrm{P}$ & $F$ & $\mathrm{~F}$ & $\mathrm{~F}$ \\
\hline & \multirow{3}{*}{$\begin{array}{l}\text { Zero } \\
\text { Carbon }\end{array}$} & D & $F$ & $F$ & $P$ & $F$ & $F$ & $\mathrm{~F}$ & $\mathbf{P}$ & $\mathbf{F}$ & $\mathbf{P}$ & $F$ & $\mathrm{~F}$ & $F$ \\
\hline & & SD & $F$ & $F$ & $P$ & $F$ & $F$ & $\mathrm{~F}$ & $F$ & $F$ & $\mathrm{~F}$ & $F$ & $\mathrm{~F}$ & $F$ \\
\hline & & MT & $\mathrm{F}$ & $\mathrm{F}$ & $\mathrm{P}$ & $\mathrm{F}$ & $F$ & $\mathrm{~F}$ & $F$ & $F$ & $\mathrm{~F}$ & $F$ & $\mathrm{~F}$ & $F$ \\
\hline \multirow{21}{*}{$\begin{array}{l}\frac{1}{0} \\
\text { ํㅜㅇ } \\
\text { के }\end{array}$} & \multirow{3}{*}{$\begin{array}{l}\text { Pre-1919 } \\
\text { baseline }\end{array}$} & D & $F$ & $F$ & $P$ & $F$ & $F$ & $\mathrm{~F}$ & $F$ & $F$ & $P$ & $F$ & $\mathrm{~F}$ & $F$ \\
\hline & & SD & $F$ & $F$ & $P$ & $F$ & $F$ & $\mathrm{~F}$ & $\underline{P}$ & $\mathbf{F}$ & $P$ & $F$ & $F$ & $F$ \\
\hline & & MT & $\mathrm{F}$ & $F$ & $P$ & $F$ & $F$ & $\mathrm{~F}$ & $F$ & $F$ & $P$ & $F$ & $\mathrm{~F}$ & $F$ \\
\hline & \multirow{3}{*}{$\begin{array}{c}1950 \mathrm{~s} \\
\text { baseline }\end{array}$} & D & $\mathrm{F}$ & $F$ & $P$ & $F$ & $F$ & $\mathrm{~F}$ & $F$ & $F$ & $P$ & $F$ & $F$ & $F$ \\
\hline & & SD & $\mathbf{P}$ & $\mathbf{F}$ & $\mathbf{P}$ & $F$ & $F$ & $\mathrm{~F}$ & $\mathbf{P}$ & $\mathbf{F}$ & $\mathbf{P}$ & $F$ & $F$ & $F$ \\
\hline & & MT & $F$ & $F$ & $P$ & $F$ & $F$ & $\mathrm{~F}$ & $F$ & $F$ & $P$ & $F$ & $\mathrm{~F}$ & $F$ \\
\hline & \multirow{3}{*}{$\begin{array}{c}2000 \text { s } \\
\text { baseline }\end{array}$} & D & $\mathbf{P}$ & $F$ & $\mathbf{P}$ & $F$ & $F$ & $\mathrm{~F}$ & $\mathbf{P}$ & $\mathbf{F}$ & $\mathbf{P}$ & $F$ & $F$ & $F$ \\
\hline & & SD & $\mathrm{F}$ & $\mathrm{F}$ & $P$ & $F$ & $F$ & $F$ & $\mathbf{P}$ & $\mathbf{F}$ & $\mathbf{P}$ & $F$ & $\mathrm{~F}$ & $F$ \\
\hline & & MT & $F$ & $F$ & $P$ & $F$ & $F$ & $\mathrm{~F}$ & $\mathrm{~F}$ & $\mathrm{~F}$ & $\mathrm{~F}$ & $F$ & $F$ & $F$ \\
\hline & \multirow{4}{*}{$\begin{array}{c}\text { Pre-1919 } \\
\text { green deal }\end{array}$} & D & $\mathrm{F}$ & $F$ & $P$ & $F$ & $F$ & $\mathrm{~F}$ & $F$ & $F$ & $\mathrm{~F}$ & $F$ & $F$ & $F$ \\
\hline & & SD & $F$ & $F$ & $P$ & $F$ & $F$ & $\mathrm{~F}$ & $F$ & $F$ & $P$ & $F$ & $F$ & $F$ \\
\hline & & MT & $\mathrm{F}$ & $F$ & $P$ & $F$ & $F$ & $\mathrm{~F}$ & $F$ & $F$ & $P$ & $F$ & $F$ & $F$ \\
\hline & & D & $\mathbf{P}$ & $F$ & $P$ & $F$ & $F$ & $\mathrm{~F}$ & $\mathbf{P}$ & $\mathbf{F}$ & $\mathbf{P}$ & $F$ & $\mathrm{~F}$ & $F$ \\
\hline & $\begin{array}{l}1950 \mathrm{~s} \\
\text { areen deal }\end{array}$ & SD & $\mathbf{P}$ & $\mathbf{F}$ & $\mathbf{P}$ & $\mathrm{F}$ & $\mathrm{F}$ & $\mathrm{F}$ & $\mathbf{P}$ & $\mathbf{F}$ & $\mathbf{P}$ & $\mathrm{F}$ & $\mathrm{F}$ & $\mathrm{F}$ \\
\hline & & MT & $\mathrm{F}$ & $\mathrm{F}$ & $P$ & $\mathrm{~F}$ & $\mathrm{~F}$ & $\mathrm{~F}$ & $\mathrm{~F}$ & $\mathrm{~F}$ & $P$ & $\mathrm{~F}$ & $\mathrm{~F}$ & $\mathrm{~F}$ \\
\hline & & D & $\mathrm{F}$ & $\mathrm{F}$ & $P$ & $\mathrm{~F}$ & $\mathrm{~F}$ & $\mathrm{~F}$ & $\mathrm{~F}$ & $\mathrm{~F}$ & $P$ & $\mathrm{~F}$ & $\mathrm{~F}$ & $\mathrm{~F}$ \\
\hline & areen deal & SD & $\mathrm{F}$ & $\mathrm{F}$ & $P$ & $\mathrm{~F}$ & $\mathrm{~F}$ & $\mathrm{~F}$ & $\mathrm{~F}$ & $\mathrm{~F}$ & $P$ & $F$ & $\mathrm{~F}$ & $\mathrm{~F}$ \\
\hline & & MT & $\mathrm{F}$ & $\mathrm{F}$ & $\mathrm{P}$ & $\mathrm{F}$ & $\mathrm{F}$ & $\mathrm{F}$ & $\mathrm{F}$ & $\mathrm{F}$ & $P$ & $\mathrm{~F}$ & $\mathrm{~F}$ & $\mathrm{~F}$ \\
\hline & & D & $\mathbf{P}$ & $\mathbf{P}$ & $\mathbf{P}$ & $\mathrm{F}$ & $\mathrm{F}$ & $\mathrm{F}$ & $\mathbf{P}$ & $\mathbf{F}$ & $\mathbf{P}$ & $\mathrm{F}$ & $\mathrm{F}$ & $\mathrm{F}$ \\
\hline & Carbon & SD & $\mathbf{P}$ & $F$ & $\mathbf{P}$ & $\mathrm{F}$ & $\mathrm{F}$ & $\mathrm{F}$ & $\mathrm{P}$ & $\mathrm{F}$ & $\mathrm{F}$ & F & $\mathrm{F}$ & $\mathrm{F}$ \\
\hline & & MT & $\mathbf{P}$ & $\mathbf{F}$ & $\mathbf{P}$ & $\mathrm{F}$ & $\mathrm{F}$ & $\mathrm{F}$ & $\mathbf{P}$ & $\mathbf{F}$ & $\mathbf{P}$ & $\mathrm{F}$ & $\mathrm{F}$ & $\mathrm{F}$ \\
\hline
\end{tabular}


Table 7 Air speed and sound measurements of domestic fans

\begin{tabular}{|l|r|r|r|r|r|r|}
\hline & \multicolumn{3}{|c|}{ Ceiling fan } & \multicolumn{3}{|c|}{ Box fan } \\
\hline $\begin{array}{l}\text { Speed } \\
\text { setting }\end{array}$ & 1 & 2 & 3 & 1 & 2 & 3 \\
\hline $\begin{array}{l}\text { Air speed } \\
\text { [m/s] }\end{array}$ & $0-0.4$ & $0.4-0.8$ & $0.8-1.2$ & 1.2 & $1.2-2.0$ & $2.0-3.0$ \\
\hline Decibels [dB] & 30 & 33 & 40 & 50 & 60 & 66 \\
\hline
\end{tabular}


Table 8 Summary of ceiling fan energy use and hours greater than $35^{\circ} \mathrm{C}$

\begin{tabular}{|c|c|c|c|c|c|c|}
\hline & \multicolumn{2}{|c|}{ Bristol } & \multicolumn{2}{|c|}{ Oxford } & \multicolumn{2}{|c|}{ Stockport } \\
\hline & [kWh] & $\begin{array}{c}\text { Hours } \\
>35\end{array}$ & [kWh] & $\begin{array}{c}\text { Hours } \\
>35\end{array}$ & [kWh] & $\begin{array}{c}\text { Hours } \\
>35\end{array}$ \\
\hline \multicolumn{7}{|c|}{$50 \%$ probability } \\
\hline Maximum & 1.9 & 3 & 1.5 & 0 & 1.0 & 0 \\
\hline Mean & 1.6 & 1 & 1.3 & 0 & 0.6 & 0 \\
\hline Minimum & 1.3 & $0^{*}$ & 0.9 & 0 & 0.3 & 0 \\
\hline \multicolumn{7}{|c|}{$90 \%$ probability } \\
\hline Maximum & 4.6 & 40 & 6.4 & 78 & 2.7 & 12 \\
\hline Mean & 4.1 & 31 & 6.0 & 68 & 2.2 & 4 \\
\hline Minimum & 3.7 & 24 & 5.4 & 56 & 1.6 & $0^{*}$ \\
\hline
\end{tabular}

* For $50 \%$ probability in Bristol and $90 \%$ probability in Stockport the maximum temperature in the Zero Carbon houses did not go above $34.9^{\circ} \mathrm{C}$, whereas all other houses did (if just once). 
Table 9 Air conditioning and boiler energy and $\mathrm{CO}_{2}$ emissions for two mid-terrace houses in Stockport at $50 \%$ probability

\begin{tabular}{|l|l|l|l|r|r|r|}
\hline & $\begin{array}{l}\text { Heating } \\
{[\mathbf{k W h}]}\end{array}$ & $\begin{array}{l}\text { Cooling } \\
{[\mathbf{k W h}]}\end{array}$ & $\begin{array}{l}\text { Total } \\
{[\mathbf{k W h}]}\end{array}$ & $\begin{array}{l}\text { Heating } \\
{\left[\mathbf{k g C O}_{2}\right]}\end{array}$ & $\begin{array}{l}\text { Cooling } \\
{\left[\mathbf{k g C O}_{2}\right]}\end{array}$ & $\begin{array}{l}\text { Total } \\
{\left[\mathbf{k g C O}_{2}\right]^{\mathbf{~}}}\end{array}$ \\
\hline Early-2000s & 3,115 & 1,136 & 4,251 & 572 & 506 & 1,078 \\
\hline Zero Carbon & 273 & 1,518 & 1,791 & 94 & 676 & 770 \\
\hline
\end{tabular}

${ }^{a}$ Current $\mathrm{CO}_{2}$ factors are used for calculations: grid electricity: $0.445 \mathrm{kgCO}_{2} \mathrm{e}$ per unit /

natural gas: $0.184 \mathrm{kgCO}_{2} \mathrm{e}$ per unit. ${ }^{46}$ 
Table 10 Energy and $\mathrm{CO}_{2}$ emissions comparison between the solar- $\mathrm{AC}$ and the heat pump for two mid-terrace houses in Stockport at $50 \%$ probability

\begin{tabular}{|l|l|r|l|r|r|r|}
\hline & $\begin{array}{l}\text { Heating } \\
{[\mathrm{kWh}]}\end{array}$ & $\begin{array}{l}\text { Cooling } \\
{[\mathbf{k W h}]}\end{array}$ & $\begin{array}{l}\text { Total } \\
{[\mathbf{k W h}]}\end{array}$ & $\begin{array}{l}\text { Heating } \\
{\left[\mathrm{kgCO}_{2}\right]}\end{array}$ & $\begin{array}{l}\text { Cooling } \\
{\left[\mathrm{kgCO}_{2}\right]}\end{array}$ & $\begin{array}{l}\text { Total } \\
{\left[\mathbf{k g C O}_{2}\right]^{\text {a }}}\end{array}$ \\
\hline Solar-AC+gas boiler \\
\hline Early-2000s
\end{tabular}

${ }^{a}$ Current carbon factors are used for calculations: grid electricity: $0.445 \mathrm{kgCO}_{2} \mathrm{e}$ per unit /

natural gas: $0.184 \mathrm{kgCO}_{2} \mathrm{e}$ per unit. $^{46}$ 
Table 11 Current and future energy and $\mathrm{CO}_{2}$ emissions for two mid-terrace houses in Oxford

\begin{tabular}{|c|c|c|c|c|c|c|}
\hline & $\begin{array}{l}\text { Heating } \\
\text { [kWh] }\end{array}$ & $\begin{array}{l}\text { Cooling } \\
\text { [kWh] }\end{array}$ & $\begin{array}{l}\text { Total } \\
\text { [kWh] }\end{array}$ & $\begin{array}{l}\text { Heating } \\
{\left[\mathrm{kgCO}_{2}\right]}\end{array}$ & $\begin{array}{l}\text { Cooling } \\
{\left[\mathrm{kgCO}_{2}\right]}\end{array}$ & $\begin{array}{l}\text { Total } \\
{\left[\mathrm{kgCO}_{2}\right]^{\mathrm{a}}}\end{array}$ \\
\hline \multicolumn{7}{|c|}{ Current condition - gas boiler ${ }^{b}$} \\
\hline Pre-1919 & 9,010 & - & 9,010 & 1,654 & - & 1,654 \\
\hline Zero Carbon & 662 & - & 662 & 166 & - & 166 \\
\hline \multicolumn{7}{|c|}{$A C+$ gas boiler at $50 \%$ probability } \\
\hline Pre-1919 & 5,439 & 1,116 & 6,555 & 999 & 497 & 1,496 \\
\hline Zero Carbon & 296 & 1,591 & 1,887 & 99 & 708 & 807 \\
\hline \multicolumn{7}{|c|}{$A C+$ gas boiler at $90 \%$ probability } \\
\hline Pre-1919 & 3,201 & 1,852 & 5,053 & 588 & 824 & 1,412 \\
\hline Zero Carbon & 178 & 1,795 & 1,973 & 77 & 799 & 876 \\
\hline \multicolumn{7}{|c|}{ Heat pump at $50 \%$ probability } \\
\hline Pre-1919 & 1014 & 755 & 1769 & 451 & 336 & 787 \\
\hline Zero Carbon & 130 & 1080 & 1210 & 58 & 481 & 539 \\
\hline \multicolumn{7}{|c|}{ Heat pump at $90 \%$ probability } \\
\hline Pre-1919 & 576 & 1258 & 1834 & 256 & 560 & 816 \\
\hline Zero Carbon & 130 & 1219 & 1349 & 58 & 542 & 600 \\
\hline
\end{tabular}

${ }^{\mathrm{a}}$ Current carbon factors are used for calculations: grid electricity: $0.445 \mathrm{kgCO}_{2} \mathrm{e}$ per unit /

natural gas: $0.184 \mathrm{kgCO}_{2}$ e per unit. ${ }^{46}$

${ }^{\mathrm{b}}$ It is assumed here that for the current climate, cooling is not necessary. 


\section{Figures}
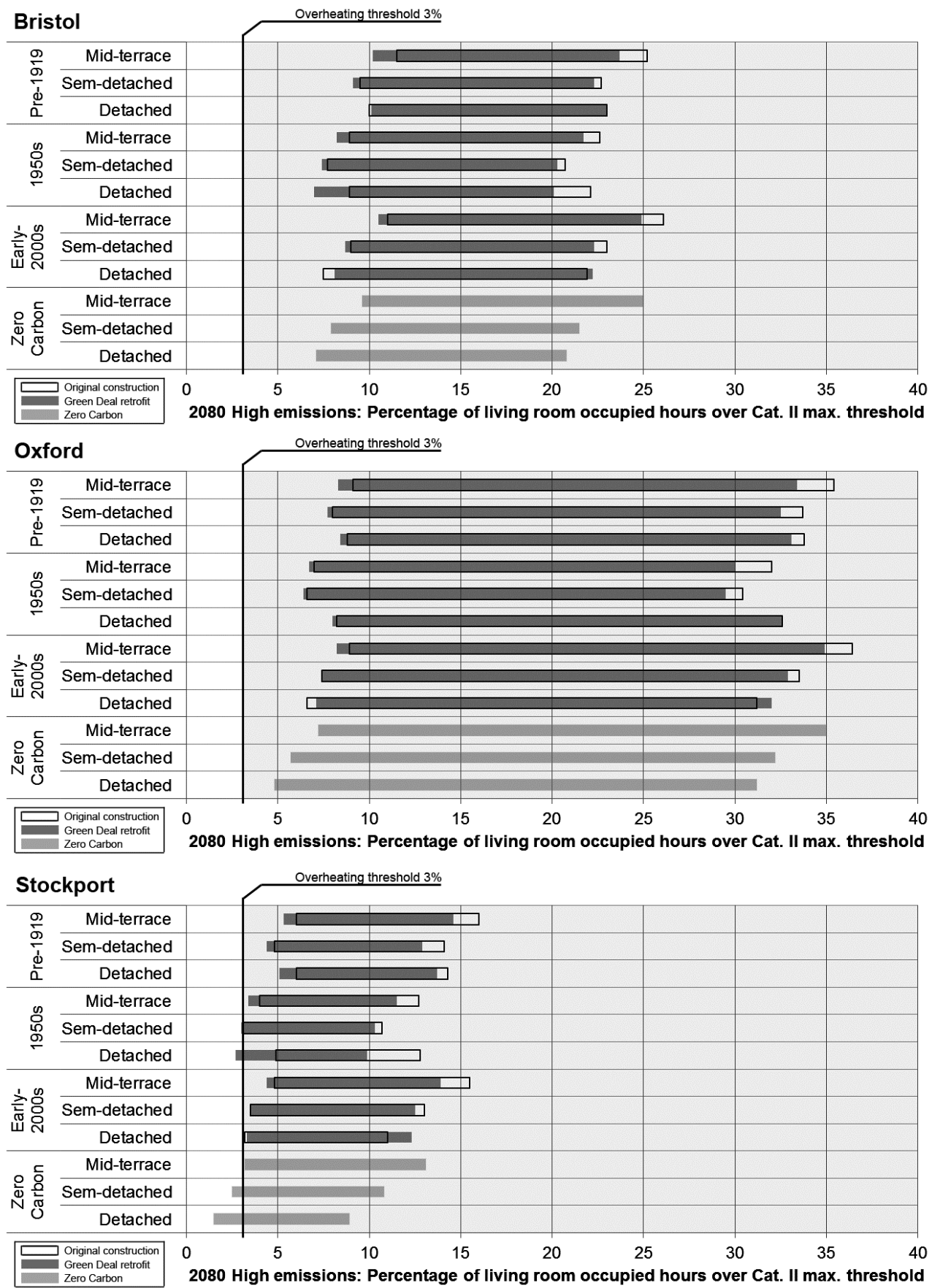

Figure 1 Bristol, Oxford and Stockport overheating. Note: the bars represent the probabilistic range of $50-90 \%$. 


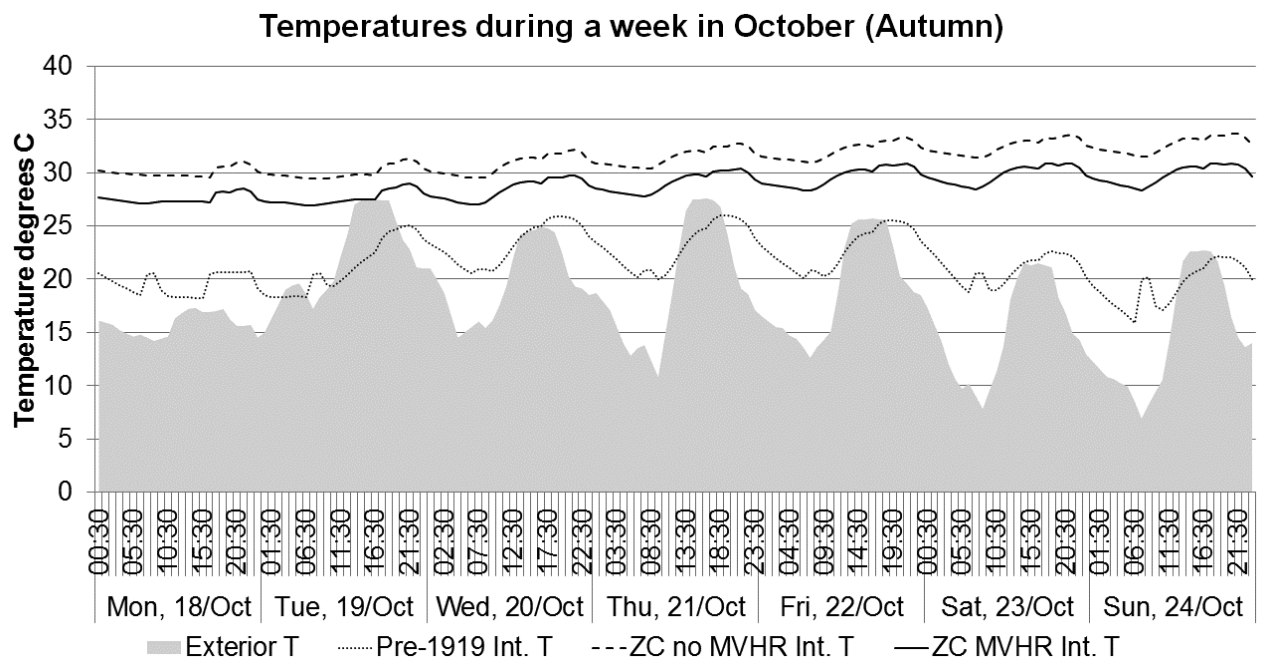

Figure 2 Bristol temperatures in three variables during the warmest week in 2080s high e. $50 \%$.

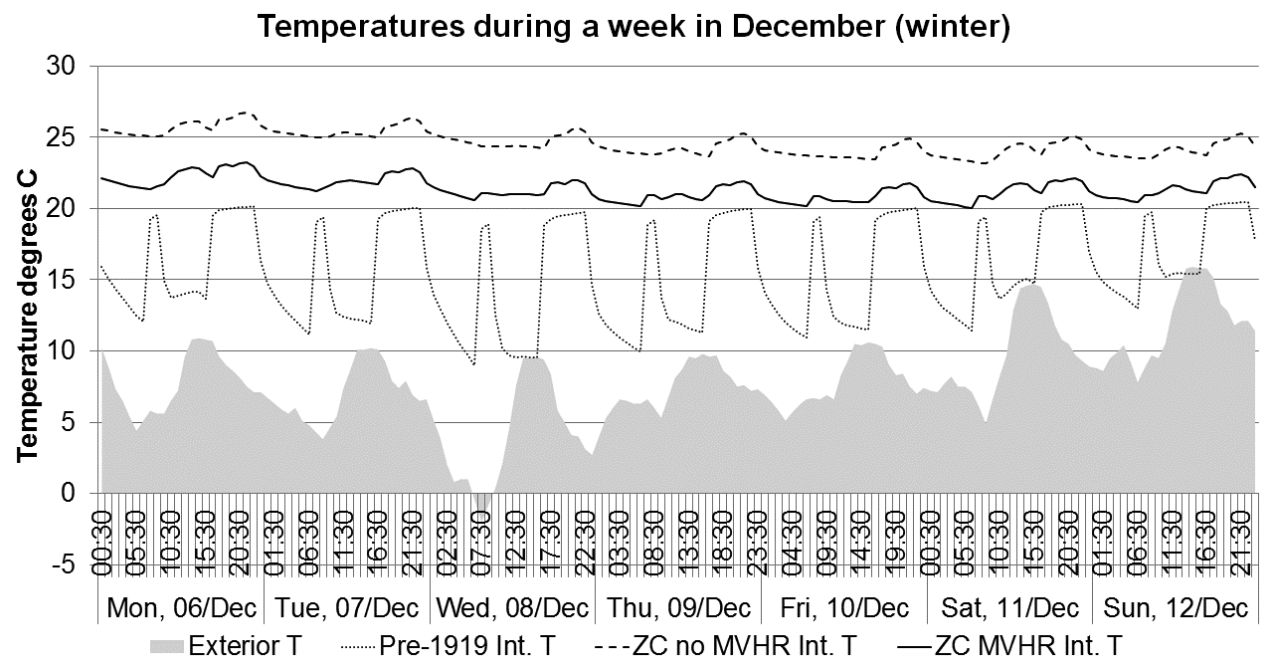

Figure 3 Bristol temperatures in three variables during the coldest week in 2080s high e. $50 \%$. 

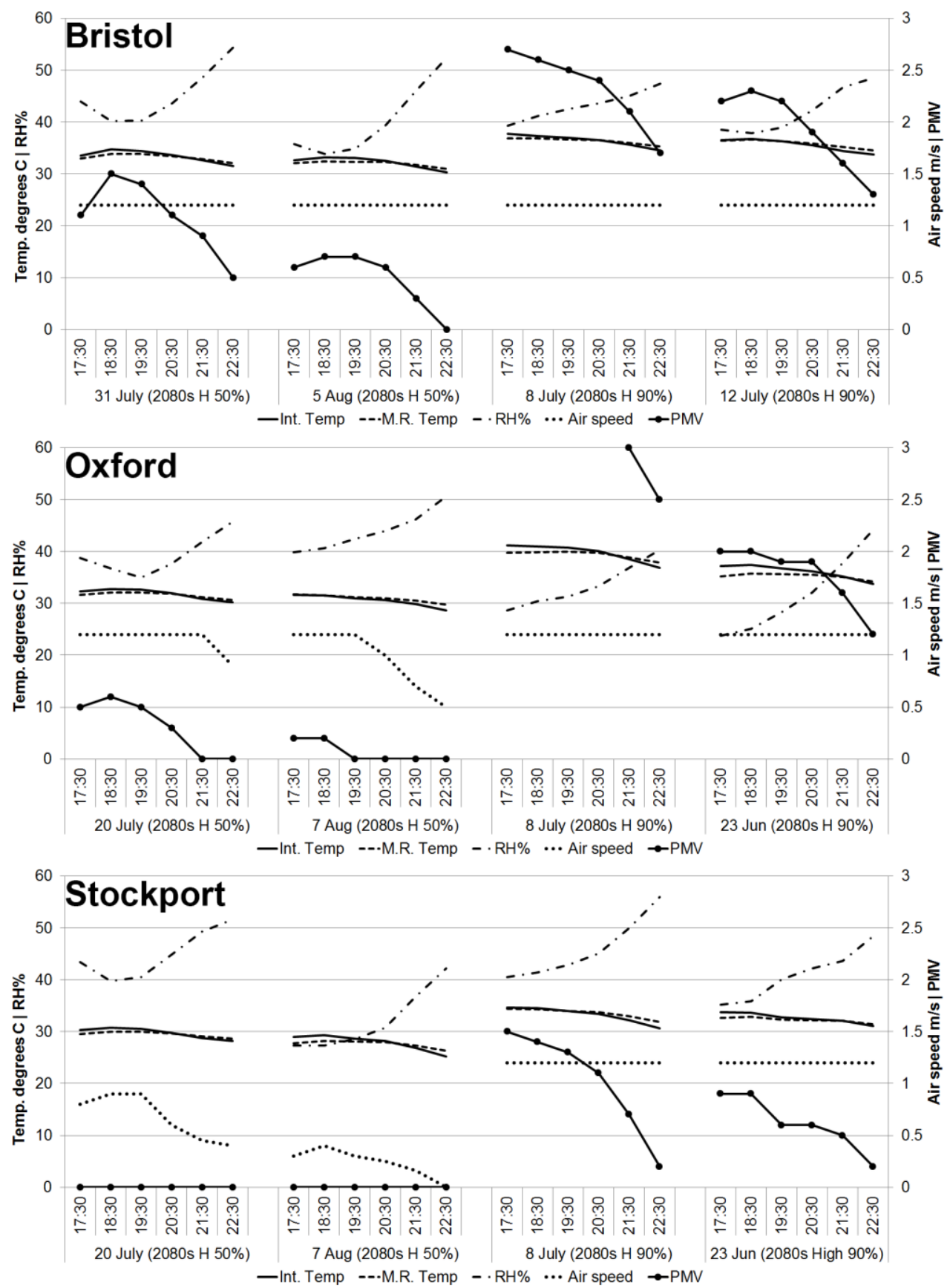

Figure 4 Internal thermal comfort conditions using a ceiling fan 

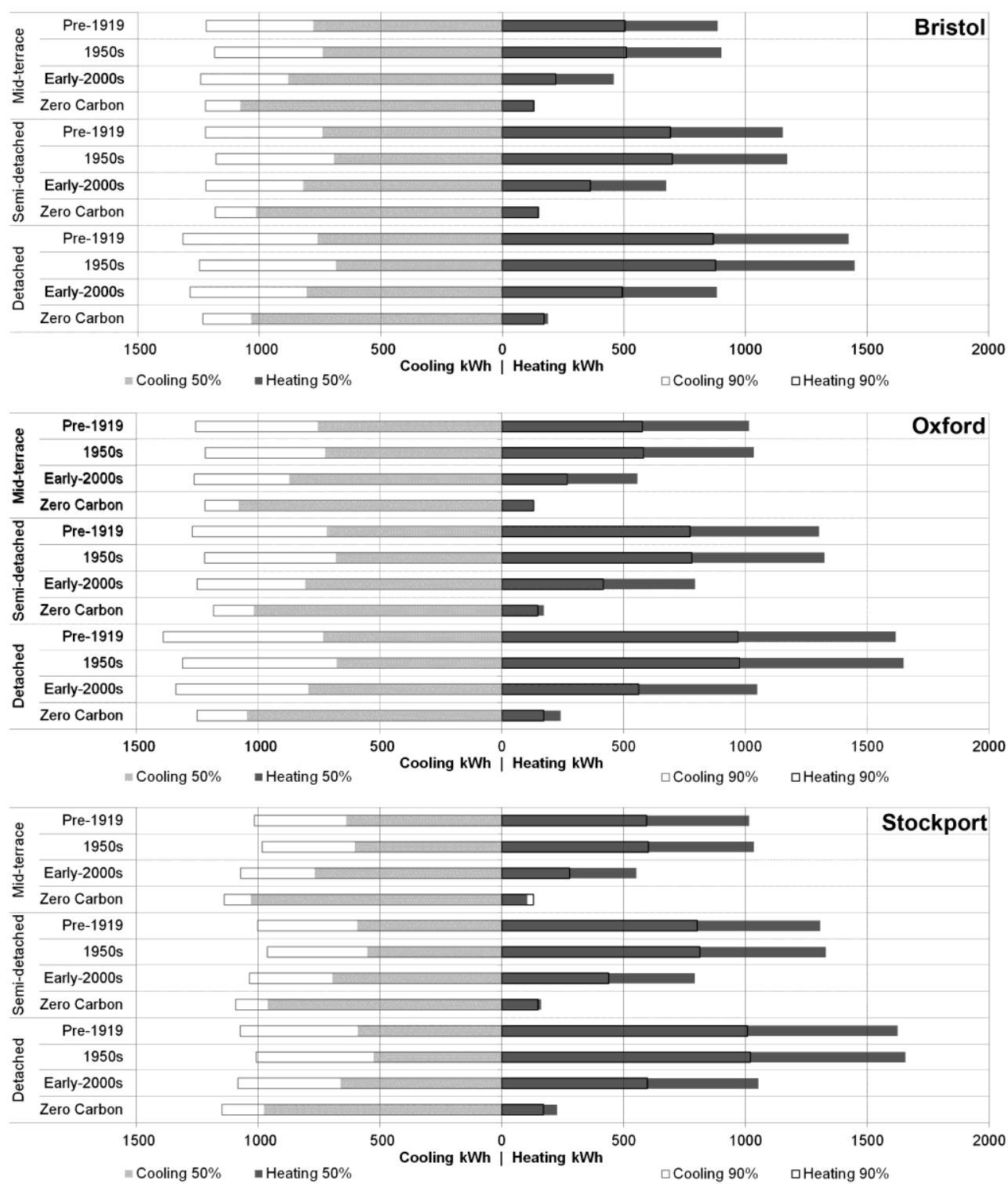

Figure 5 Heat pump space heating and cooling energy use 


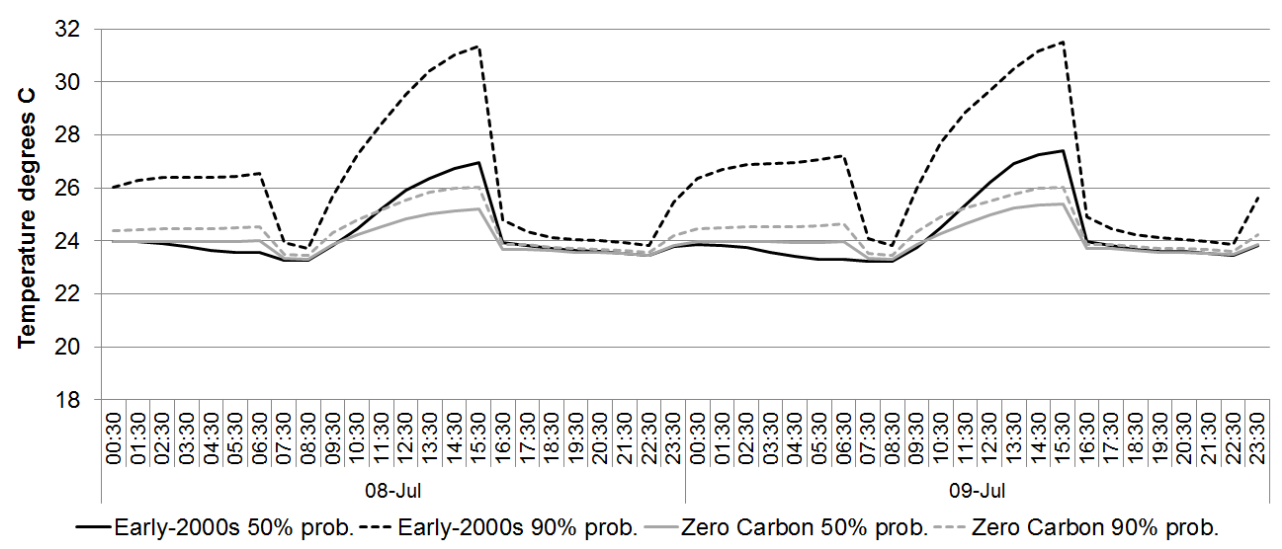

Figure 6 Temperature swing comparisons for two houses in Oxford at 50 and $90 \%$ probability 

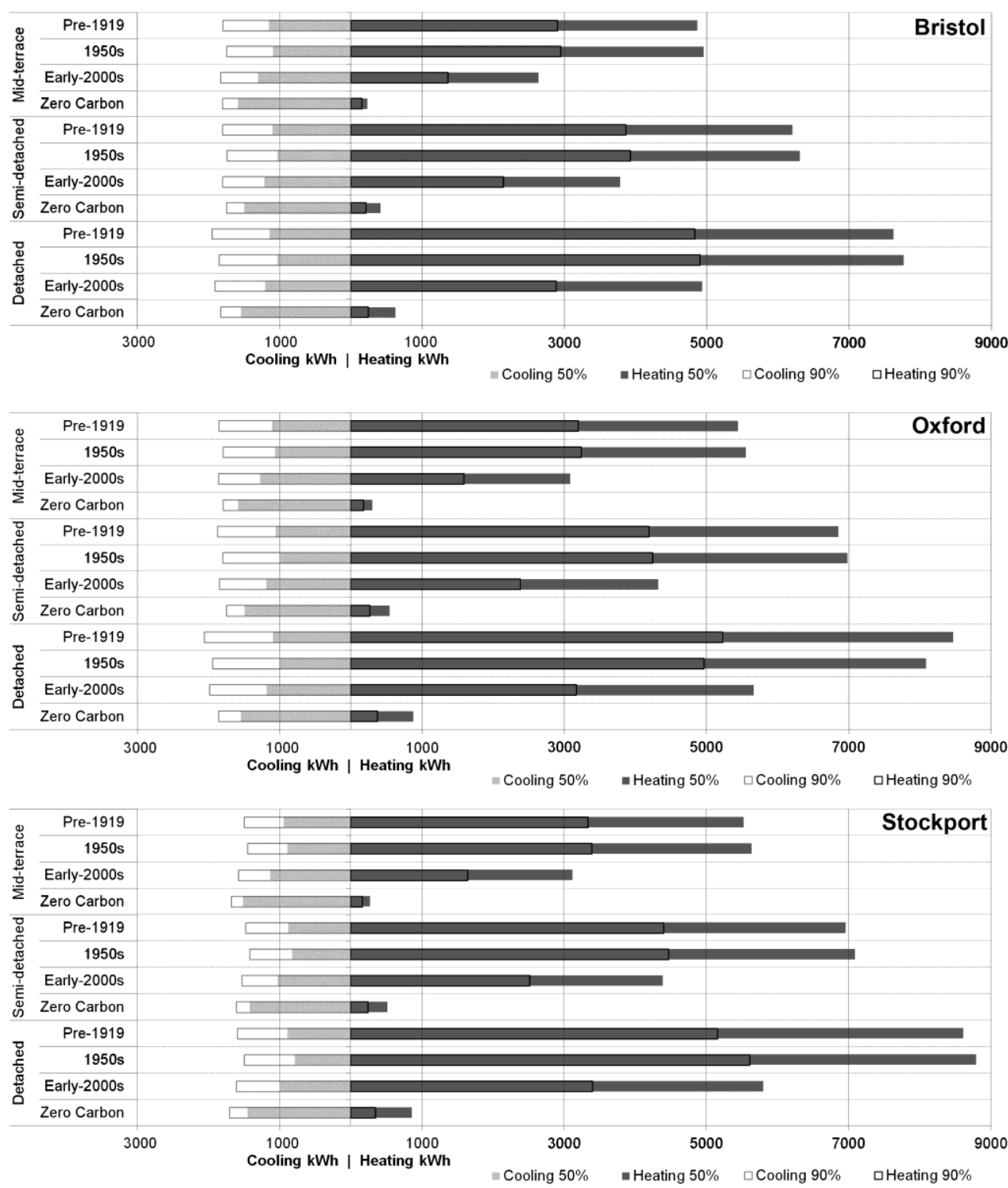

Figure $7 \mathrm{AC}$ and gas boiler energy consumption 


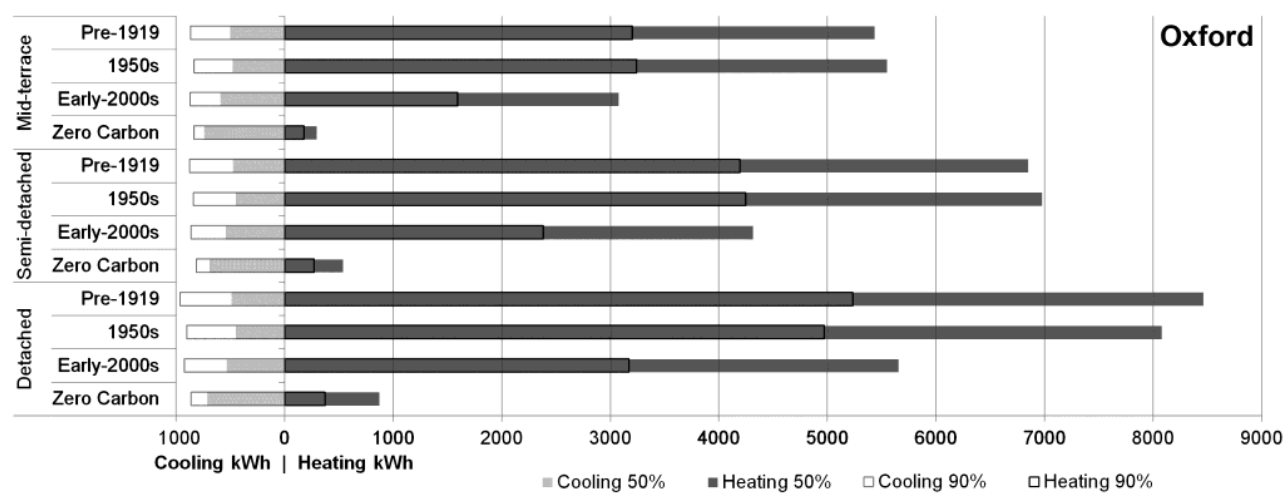

Figure 8 Oxford solar-AC and gas boiler energy consumption

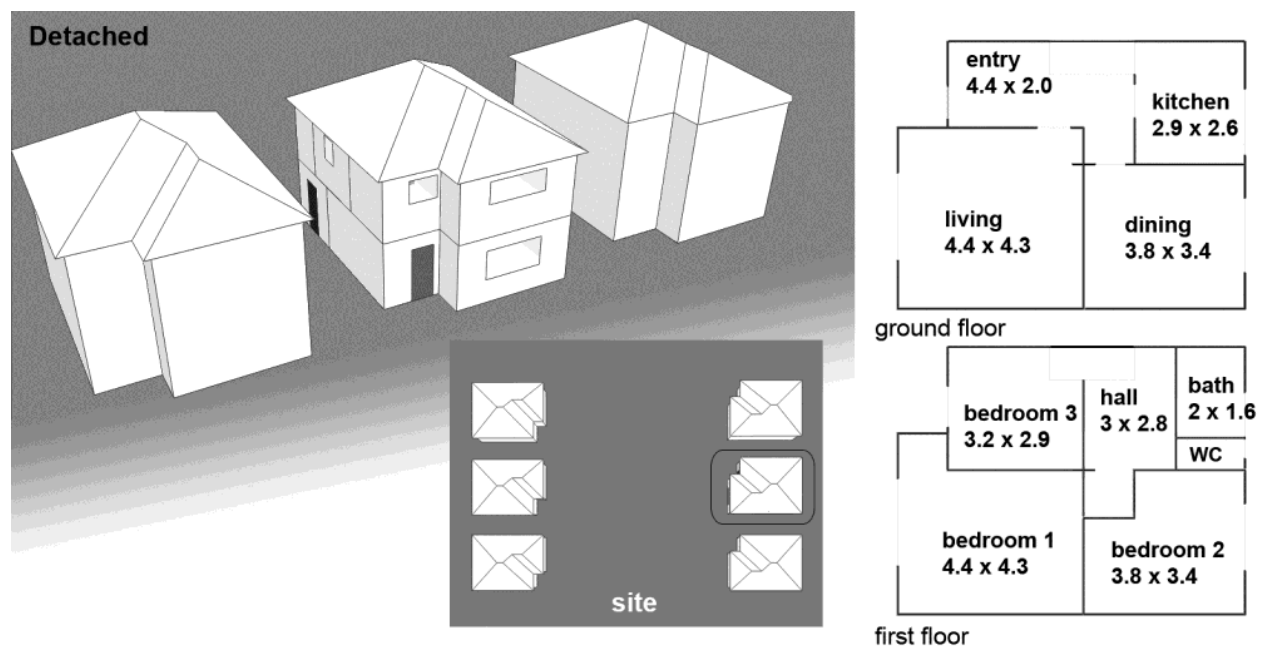

Figure A.1 Perspective image, site plan and floor plans of the detached home

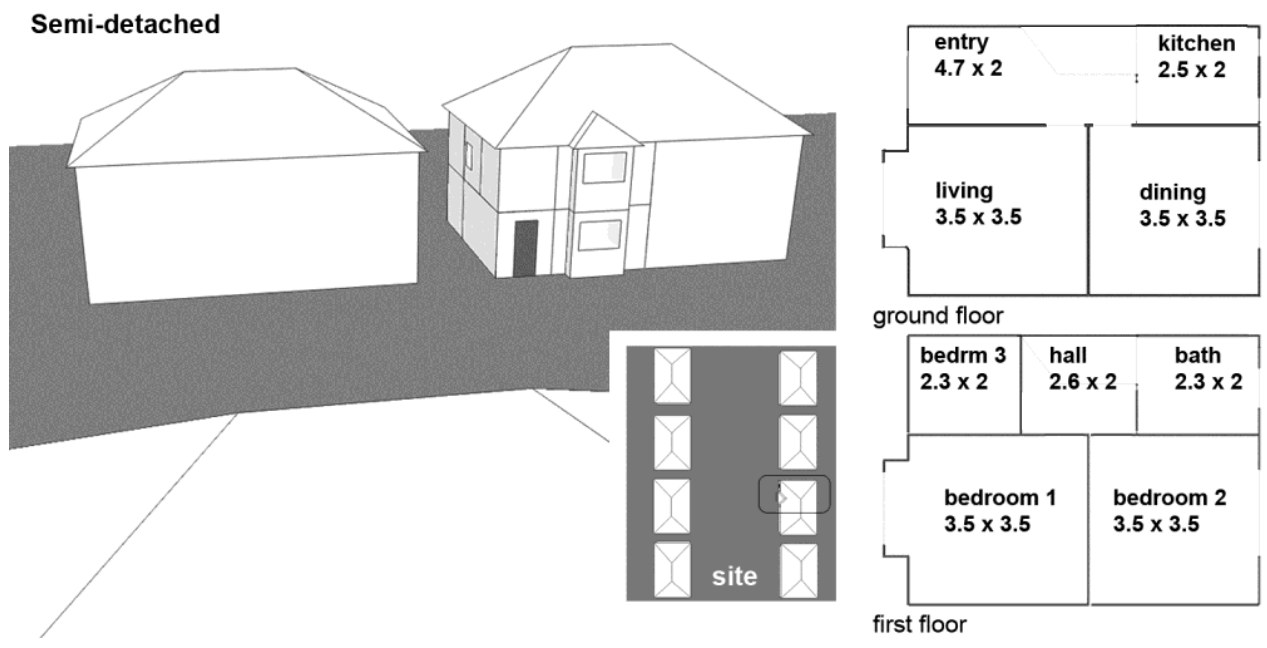

Figure A.2 Perspective image, site plan and floor plans of the semi-detached home 

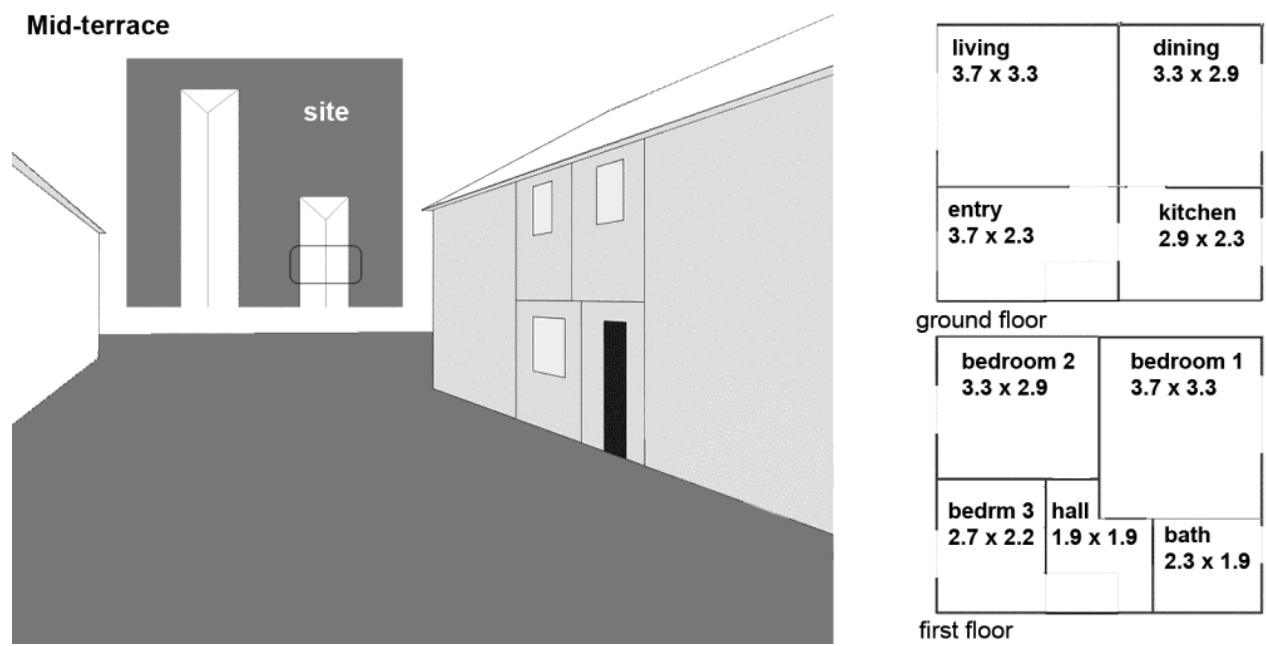

Figure A.3 Perspective image, site plan and floor plans of the mid-terrace home 


\section{Endnotes}

\footnotetext{
i The Green Deal is a UK Government initiated private investment in the carbon reduction of existing building stock. Energy efficiency improvements will be offered by the private sector to homeowners and businesses at little or no upfront cost with payment recouped through customers' energy bills. ${ }^{24}$
}

ii IES VE was selected partly due to the wide international use by both research and practice communities, and the extensive historical testing and verification. ${ }^{50,51,52}$ Building models are simplifications of reality; to add to this, there is inevitable uncertainty to model predictions when it comes to simulating a number of variables, e.g. occupant patterns, heating and cooling systems and air permeability rates. This is further intensified when considering the uncertainties of FWYs and climate change modelling.

iii The Golden Rule is the central mechanism for determining which measures can be financed by using the Green Deal. The rule: "Estimated savings must be greater than or equal to repayments." The caveat: "Actual savings may be less than these repayments (if your energy use changes or if energy prices fall)". ${ }^{24}$

iv The new approach to meet Zero Carbon has been defined as a tiered process which includes, first, fabric improvement; second, low carbon heat and power technologies; and third, further reduction of regulated emissions if necessary via 'allowable solutions' (e.g. carbon funds, extension of district heating network to neighbouring development). ${ }^{47}$ 